\title{
Purines as potential morphogens during embryonic development
}

\author{
Karine Massé • Nicholas Dale
}

Received: 24 October 2011 / Accepted: 4 January 2012 / Published online: 25 January 2012

(C) The Author(s) 2012. This article is published with open access at Springerlink.com

\begin{abstract}
Components of purinergic signalling are expressed in the early embryo raising the possibility that ATP, ADP and adenosine may contribute to the mechanisms of embryonic development. We summarize the available data from four developmental models-mouse, chick, Xenopus and zebrafish. While there are some notable examples where purinergic signalling is indeed important during development, e.g. development of the eye in the frog, it is puzzling that deletion of single components of purinergic signalling often results in rather minor developmental phenotypes. We suggest that a key step in further analysis is to perform combinatorial alterations of expression of purinergic signalling components to uncover their roles in development. We introduce the concept that purinergic signalling could create novel morphogenetic fields to encode spatial location via the concentration of ATP, ADP and adenosine. We show that using minimal assumptions and the known properties of the ectonucleotidases, complex spatial patterns of ATP and adenosine can be set up. These patterns may provide a new way to assess the potential of purinergic signalling in developmental processes.
\end{abstract}

Keywords Embryogenesis · Neurulation · Gastrulation · Organogenesis · Morphogen $\cdot$ ATP $\cdot$ Adenosine $\cdot$ ADP

K. Massé

Univ. Bordeaux, CIRID, UMR 5164,

F-33000 Bordeaux, France

K. Massé

CNRS, CIRID, UMR 5164,

F-33000 Bordeaux, France

N. Dale $(\bowtie)$

School of Life Sciences, University of Warwick,

Coventry, UK

e-mail: n.e.dale@warwick.ac.uk

\section{Introduction}

ATP has a central role as the universal energy store in cellular metabolism. However, ATP is also used as an extracellular signalling molecule in many diverse contexts $[1,2]$ —including in the peripheral organs, the brain and most relevant to the context of this review, during embryonic development.

ATP can act at both ionotropic (P2X) [3] and metabotropic receptors (P2Y) [4]. However, it differs from many other chemical signalling agents in the body in that it can be broken down in the extracellular space to a number of other molecules some of which retain biological signalling activity at distinct sets of receptors. For example, the first breakdown product, ADP, can act at P2Y1, P2Y12 and P2Y13 receptors [4]. Adenosine, a later product in the extracellular catabolic cascade can act at four distinct G-protein-coupled receptors $\left(\mathrm{A}_{1}\right.$, $\mathrm{A}_{2 \mathrm{~A}}, \mathrm{~A}_{2 \mathrm{~B}}$ and $\mathrm{A}_{3}$ ) [5]. The extracellular enzymes that control the metabolism of ATP in the extracellular space, therefore do much more than terminate the actions of ATP, they can also initiate the actions of downstream signalling molecules. In considering the potential roles of purinergic signalling during development, it is therefore very important to take into account not just the various receptor families, but also the diverse enzyme families that break down ATP. There are at least four gene families that encode ectoenzymes relevant to the breakdown of ATP. These include the ENTPDases (related to CD39), the ENPPases, alkaline phosphatases and ecto-5' nucleotidase (5'NT, also known as CD73) [6, 7].

The complexity of purinergic signalling has the potential to offer new mechanisms to control developmental events. During embryogenesis, pluripotent cells become progressively restricted to one fate. These differentiated cells are then organised inside a tissue or organ where they are specialised for particular functions. Cell-to-cell interactions, some of which will be mediated by diffusible signals, play 
crucial roles in the spatial and temporal control of the generation and arrangement of these distinct specialised cell types. Exemplars of all the components of purinergic signalling display specific expression patterns during very early development. This suggests that developmental processes may indeed avail themselves of the potential complexity inherent in purinergic signalling.

In this review, we shall not consider data obtained in vitro or in postnatal studies. Instead, we shall focus on the four vertebrates that are extensively used as models in developmental biology: chick, mouse, Xenopus and zebrafish (Fig. 1). We do not intend to present a comprehensive overview of purinergic signalling during neuronal development. We refer the readers to other very good reviews [8-10]. Instead, we seek to address the potential roles of purinergic signalling more generally in very early development.

Our aim is to present a novel view on how purinergic signalling may act during embryogenesis. We start first by briefly summarizing the four major developmental models, and then consider in detail the expression profile during development of the major purinergic components, i.e. the ectonucleotidases and the purinergic receptors. After this, we review the phenotypes induced following alteration (genetic, pharmacological) of key components of purinergic signalling. We then consider from a more theoretical perspective the potential of purinergic signalling agents as novel morphogens. To do this, we firstly consider an established morphogen, retinoic acid (RA), and then by comparison demonstrate how simulations incorporating known properties of the ectonucleotidases can result in spatial patterns of ATP and adenosine to provide the potential for morphogenetic fields of greater complexity than those described for RA.

\section{Models of development}

As many coming to this field may not be fully familiar with the four developmental models (chick, mouse, Xenopus and zebrafish) that we consider in our review, we shall give a brief account of their embryonic development. This is important because we wish to establish common development stages between the four models ultimately to allow abstraction of general principles with regard to the contribution of purinergic signalling. As the four model organisms develop

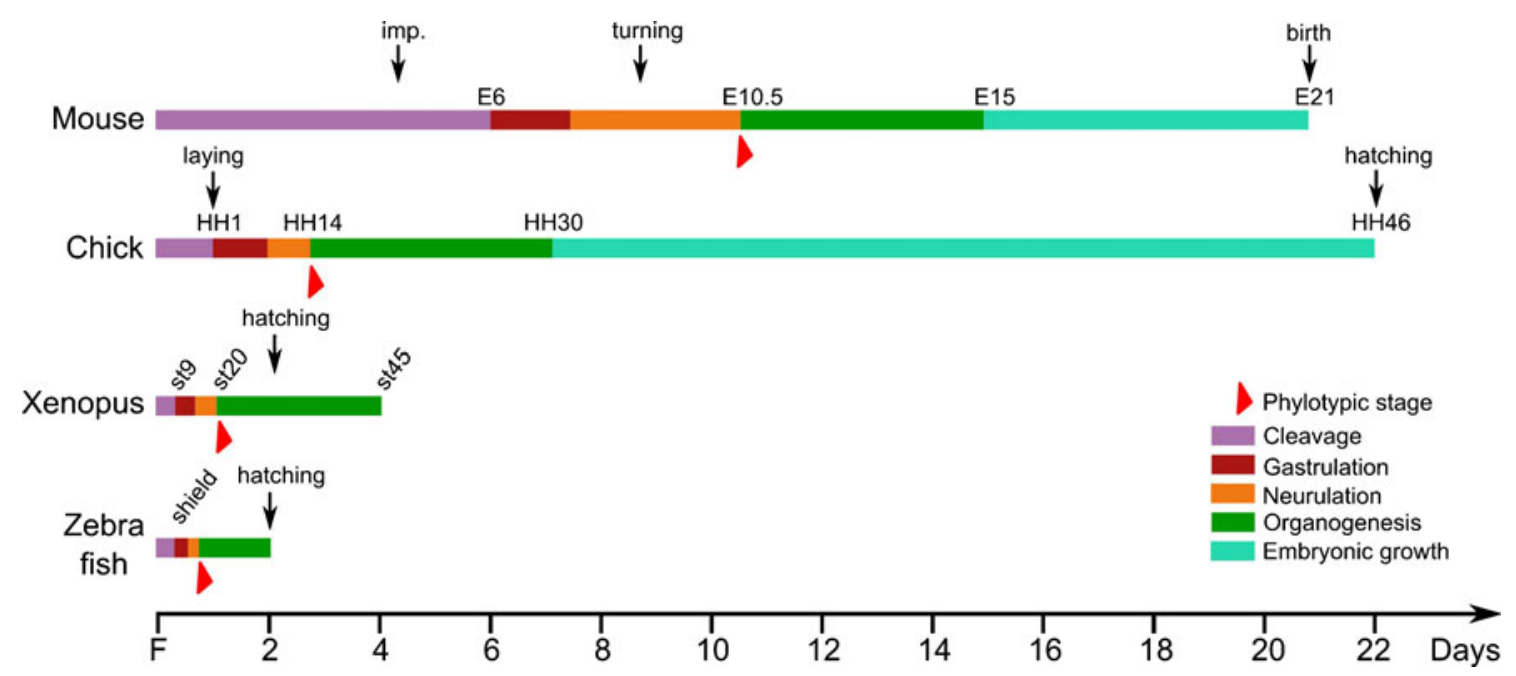

Fig. 1 Comparative embryogenesis of the mouse, chick, Xenopus and zebrafish. After fertilization $(F)$, these four vertebrates undergo similar phases during their embryonic life. Species-specific stages are indicated on the figure. Briefly, Mouse embryos will implant (imp) at E4.5, after formation of the blastocyst and separation between the epiblast (or primitive ectoderm), at the origin of the embryo, and the cells which will give rise to the extra embryonic structures, the trophoectoderm and the primitive endoderm. The turning process, at E9, allows the establishment of the dorsal and ventral axis. The organogenesis is followed by the embryonic or foetal growth phase and birth takes place between 18 to 21 days after fertilization, depending on the mouse strain. The cleavage phase of the Chick embryos takes place in the hen oviduct. After laying, gastrulation and neurulation are complete in 2 days and stage HH14 is characterized by the existence of 22 somites. Feather germs appear at stage $\mathrm{HH} 3 \mathrm{O}$ and organogenesis and embryo growth continue till hatching 22 days after fertilization. Cleavage of Xenopus embryos will be complete by stage 9, blastula stage and neurulation starts at stage 12.5 and ends at stage 20. First somite is formed at stage 17. Organogenesis is the longest phase, characterized by the hatching of the embryos from their vitelline membrane around stage 25. After stage 45 , the tadpole will start feeding and will undergo the metamorphosis phase before becoming an adult frog. Zebrafish embryos display the quickest embryonic life cycle. Cleavage divisions lead to the formation of a blastoderm lying over the yolk, at the sphere stage, $4 \mathrm{~h}$ after fertilization. Gastrulation starts $5.5 \mathrm{~h}$ after fertilization, at the shield stage and is complete only $4.5 \mathrm{~h}$ later. Somite formation and neurulation follow during the segmentation period. Organogenesis then takes place during the pharyngula period, less than $24 \mathrm{~h}$ after fertilization, and zebrafish embryo usually hatches 48 to $72 \mathrm{~h}$ after fertilization. The term larva is being arbitrarily used after the end of the third day, whether the hatching has taken place or not 
rather differently and on very different timescales, this can be a challenge for newcomers to developmental biology.

The four vertebrate model organisms commonly used for developmental work have distinct advantages and disadvantages, which are summarized in Table 1. Being the only mammalian model with a relatively short embryonic life cycle of 3 weeks together with the ease of making genetic modifications, the mouse has become a model of choice for many developmental biologists. However, the inaccessibility of the embryo and the difficulty of in vivo manipulation is a serious technical barrier for investigation of gene function during early development phases.

Avian embryos are very similar to the mammalian ones in the general course of embryonic development, and as the embryo is accessible, are very good for manipulative embryology. However, the development is not external and chick embryos are quite difficult to breed.

Xenopus and zebrafish embryos exhibit external development, rapid generation times and are easy to maintain. These embryos therefore display great advantages as models for development. A unique complication of Xenopus laevis is that the genome is pseudotetraploid, rather than diploid. Whereas, this genome has not been sequenced, that of Xenopus tropicalis has, and this close relative has the advantage of a diploid genome [11].

Despite their anatomical and embryonic cycle length differences, a broadly similar set of developmental stages can be defined for these 4 vertebrate models (Fig. 1). After fertilization, the zygote undergoes cleavage. This stage is composed by rapid cell divisions, initially without an increase in overall mass of the embryo. The pattern of these divisions is quite diverse depending on the yolk richness and distribution in the egg. However, this cleavage period leads to a formation of cell mass whose shape differs, but is equivalent to the Xenopus blastula. Xenopus embryos develop from the entire egg mass whereas the zebrafish embryo develops only around the large mass of yolk. Chick and mouse embryos derive from a layer of epithelium called the epiblast as other cells will be involved in the formation of extra embryonic structures. This stage is followed by gastrulation, the fundamental process which shapes the features of the developing animal with the induction of the three germ layers: ectoderm which will give rise to the epidermis and neural tissues, endoderm which will generate the digestive tube and accessory organs and mesoderm which will form muscles, cardiovascular and skeletal elements [12]. This process involves four major evolutionary conserved morphogenetic movements (internalization, epiboly, convergence and extension), which allow the internalization of the mesodermal and endodermal cells whereas the ectodermal cells surround the embryo. Inductive processes specify and pattern these germ layers, which are controlled by the key signalling centre called the organizer (Spemann-
Mangold centre in Xenopus, the embryonic shield in zebrafish, the Hensen's node in chick and the node and AVE (anterior visceral endoderm) in mouse). Onset of gastrulation is characterized by the appearance of the blastopore, which marks the future dorsal side of the Xenopus embryo and in zebrafish by the formation of the shield-shaped region, indicating the shield stage. Chick and mouse gastrulation is marked by the convergence of the epiblast cells towards the primitive streak, similar to the amphibian blastopore. Gastrulation is then followed by neurulation, the formation of the neural tube. Notochord and somites, at the origin of the vertebrate column and trunk and limbs muscles, are formed or start to appear during the neurula stage.

Although early developmental phases differ, all vertebrate embryos pass through the phylotypic stage, the stage at which they all look rather similar and exhibit the specific features of chordate embryos (a neural tube running along the dorsal midline on top of the notochord flanked on either side by the somites). Organogenesis comprises the final embryonic stage and will allow the formation of internal organs and specific features such as beaks, wings, legs, fins.

Reliable ways of identifying specific developmental stages are essential for the analysis of embryonic development. The easiest method is the time from fertilization. Mouse embryos are most often referred to by their embryonic age (E) days post coitum, since their temperature is constant. However, they can be staged according to criteria described by Theiler [13] or by Downes and Davies [14]. However, time from fertilization cannot be used for Xenopus embryos as their developmental speed is temperature dependent. Other criteria, based on embryonic morphology, have been developed and are described in the tables of Nieuwkoop and Faber [15]. Numbered stages, known as HH stages (Hamburger and Hamilton), mostly based on the number of somites, have been identified for chick embryos [16]. Zebrafish embryos are identified by the criteria published by Kimmel et al. [17], especially during the first $24 \mathrm{~h}$.

The key comparison across the four models in understanding gene expression patterns is not the absolute time of development, but the developmental stage. With accurate staging, it becomes possible to normalize the different developmental stages thus allowing comparison of the pattern of expression of purinergic signalling components across the different models (Fig. 2).

\section{Expression patterns during early development}

It is self-evident that to influence early development, a gene must be expressed at an appropriate time. Therefore, the logical beginning of any investigation into whether purinergic signalling plays a role in embryogenesis resides in 
Table 1 Characteristics, advantages and disadvantages of the four major vertebrate model organisms

\begin{tabular}{|c|c|c|c|c|}
\hline & Chick & Mouse & Хепориs & Zebrafish \\
\hline Development & $\begin{array}{l}\text { Internal (oviduct for } \\
\text { cleavage stage)/external }\end{array}$ & In utero & External & External \\
\hline Developmental specificity & $\begin{array}{l}\text { Early development like } \\
\text { mammals (primitive streak) }\end{array}$ & Mammalian & Metamorphosis & $\begin{array}{l}\text { Early development phases } \\
\text { quite different to other } \\
\text { vertebrates. }\end{array}$ \\
\hline $\begin{array}{l}\text { Developmental cycle } \\
\text { length }\end{array}$ & 22 days & $18-21$ days & $\begin{array}{l}4 \text { days (at } 23^{\circ} \mathrm{C} \text { ), } \\
\text { temperature dependent }\end{array}$ & 2-3 days \\
\hline Offspring & $<10$ & $<10$ & $10^{3}$ & $10^{2}$ \\
\hline Oocyte size (diameter) & $2.5 \mathrm{~cm}$ & $80-100 \mu \mathrm{m}$ & $1.2-1.4 \mathrm{~mm}$ & $0.7 \mathrm{~mm}$ \\
\hline $\begin{array}{l}\text { Maintenance and } \\
\text { breeding }\end{array}$ & $\begin{array}{l}\text { Easy but need to obtain } \\
\text { laid eggs }\end{array}$ & Difficult and expensive & Very easy & Very easy \\
\hline Manipulative embryology & $\begin{array}{l}\text { Access through the egg shell } \\
\text { (graft, beads implantation) }\end{array}$ & $\begin{array}{l}\text { Only for embryos up to } \\
\text { blastocyst stage but } \\
\text { need to be re-implanted }\end{array}$ & $\begin{array}{l}\text { Microsurgery, graft, } \\
\text { fate mapping }\end{array}$ & $\begin{array}{l}\text { Microsurgery, fate } \\
\text { mapping }\end{array}$ \\
\hline Genome & Sequenced $\left(1.2 \times 10^{9}\right)$ & Sequenced $\left(3 \times 10^{9}\right)$ & $\begin{array}{l}\text { Tetraploid genome not } \\
\text { yet sequenced but } \\
X \text { tropicalis genome } \\
\left(1.8 \times 10^{9}\right) \text { sequenced }\end{array}$ & $\begin{array}{l}\text { Sequenced }\left(1.7 \times 10^{9}\right) \\
\text { duplicated genome }\end{array}$ \\
\hline $\begin{array}{l}\text { Genetics based } \\
\text { techniques }\end{array}$ & $\begin{array}{l}\text { Spontaneous mutations, gene } \\
\text { silencing (RNAi), electroporation, } \\
\text { transgenic animal (lentivirus), } \\
\text { ES cells }\end{array}$ & $\begin{array}{l}\text { Electroporation, } \mathrm{KO}, \mathrm{KI}, \\
\text { conditional } \\
\text { transgenesis }\end{array}$ & $\begin{array}{l}\text { Gene silencing (MO), } \\
\text { gain of functions } \\
\text { (injection RNA, } \\
\text { protein, DNA), } \\
\text { transgenic animal } \\
\text { (REMI) }\end{array}$ & $\begin{array}{l}\mathrm{KO} \text {, gene silencing and } \\
\text { gain of functions as } \\
\text { Xenopus embryos but no } \\
\text { targeted injections }\end{array}$ \\
\hline Screens & $\begin{array}{l}\text { Mutation screens (but costly } \\
\text { and difficult) }\end{array}$ & Mutation screens & $\begin{array}{l}\text { Pharmacological and } \\
\text { mutation screens }\end{array}$ & $\begin{array}{l}\text { Pharmacological and } \\
\text { mutation screens }\end{array}$ \\
\hline Specific advantages & Chimera & ES cells, iPS & $\begin{array}{l}\text { Targeted injections, high } \\
\text { resistance to infections }\end{array}$ & Transparency of embryos \\
\hline Website & & MGI & Xenbase & ZFIN \\
\hline
\end{tabular}

$E S$ embryonic cells, iPS induced pluripotent cells, $K O$ knock-out, $K I$ knock-in, MO morpholino oligonucleotide, REMI restriction enzymemediated insertion

determining the expression patterns of its key players, the ectonucleotidases and purinergic receptors.

Several studies have been performed to characterize the spatial and temporal expression profile of purinergic signalling components in developing embryos (Table 2, Fig. 2). These data demonstrate that there is indeed potential for ATP, ADP and adenosine-mediated signalling to be involved at all stages, from cleavage to organogenesis. However, an important point is the extent to which these studies are comprehensive - absence of evidence is not the same as evidence of absence. Therefore we also list studies that demonstrate the lack of expression of several receptors and enzymes during embryonic development (Table 3).

Most data are available for the mammalian embryos. However, few of these studies have investigated the expression of these genes in the entire embryo, and most have focussed on one specific organ. One useful way of determining expression patterns is to generate a knock-out $(\mathrm{KO})$ by insertion of the $\beta$-gal gene into the relevant locus. The expression of lacZ is directly under the control of the promoter of the gene of interest, thus lacZ expression easily demonstrates the expression profile of the mutated gene. Several KO mice of purinergic signalling components have been generated in this way. Disappointingly, however, the distribution of lacZ staining throughout embryogenesis has not been reported [18-24]. We suggest that use of this tool would be a relatively easy and extremely useful way to determine the expression of these genes in the entire mouse embryo.

\section{Purinergic receptors}

Most of the purinergic receptors are expressed in the mouse embryo at some point (Fig. 2). However, this survey is not comprehensive as some of these data come from databases $[25,26]$ (BGEM website: http://www.stjudebgem.org/web/ mainPage/mainPage.php; Eurexpress website: http://www. eurexpress.org/ee/) for which expression has only been investigated at one or two embryonic stages. Except for P2X3 [27], most of the information available comes from the stages of organogenesis and foetal growth. This may be due to difficulty of extracting mouse embryos before E7/ 7.5 , the start of neurulation. 


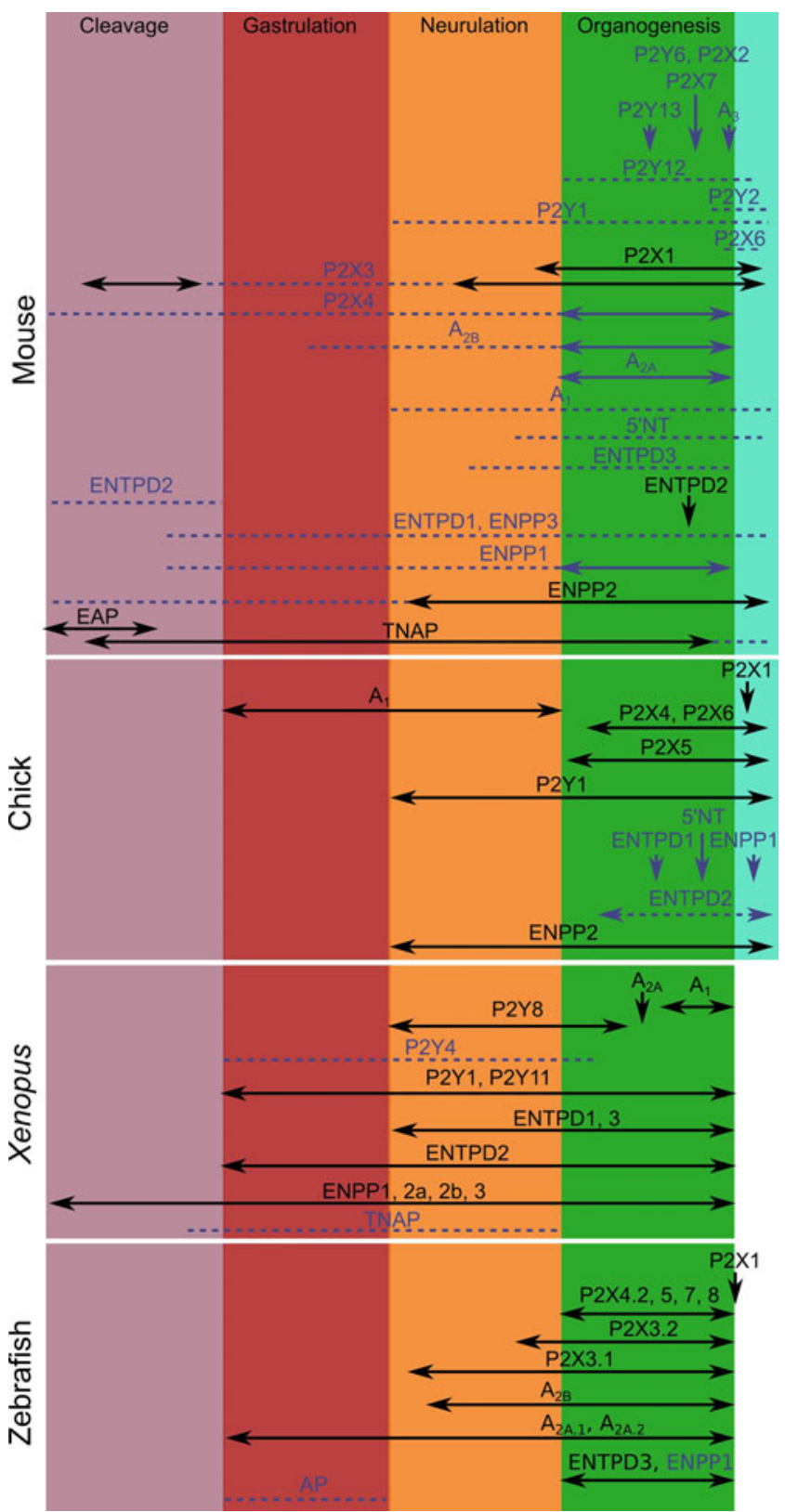

Fig. 2 Temporal pattern of expression of the purinergic signalling components in mouse, chick, Xenopus and zebrafish embryos. The extent of expression of purinergic receptors and ectonucleotidases is mapped along the major phases of embryogenesis, cleavage, gastrulation, neurulation and organogenesis and embryo growth that have been normalized in duration for the four model organisms to allow easier comparison. The expression of some of these genes has only been described at one stage (indicated by arrows). EST expression data is indicated by blue dashed lines and corresponding gene names in blue. The expression of mouse genes published in [25] or [26] as part of the embryonic mouse database and atlas of gene expression are indicated by solid blue lines. The murine $P 2 Y 1$ expression by in situ hybridization is available on the MGI website

Expressed Sequence Tag (ESTs) databases have been generated for in silico analysis. The UniGene database (http://www.ncbi.nlm.nih.gov/UniGene) gives information for each gene about its transcripts and ESTs, genomic location and expression. Although being developed in several vertebrate species, the database for mouse is one of the most advanced. Analysis of the UniGene for purinergic receptors clearly indicates expression of these receptors at all embryonic stages of mouse embryos especially during the early phases. ESTs have been identified for P2X3, P2X4, P2Y1, $\mathrm{A} 1$ and $\mathrm{A} 2 \mathrm{~b}$ during zygote, cleavage and gastrula stages.

Fewer P2 and P1 receptors have been cloned in chick, Xenopus and zebrafish. Nevertheless, expression studies have demonstrated the presence of P2X, P2Y and adenosine receptors from gastrulation stages, suggesting that ATP, ADP and adenosine may also play a role during very early phases of development in non-mammalian species. The comparative expression profile of the $\mathrm{P} 2 \mathrm{X}$ genes demonstrated that these receptors have distinct patterns of expression during zebrafish development suggesting specific roles for each P2X receptor subtype [28]. Adenosine signalling may also be important in early development as $A_{1}$ and $A_{2}$ receptors are expressed from the gastrulation stage in chick and zebrafish embryos respectively [29].

Interestingly, there is evidence that P2X5, P2Y12, P2Y13 and $\mathrm{P} 2 \mathrm{Y} 14$ are not expressed at E14.5, during organogenesis [26] (Table 3). However, ESTs for P2Y12 and P2Y13 have been identified in organogenesis and foetal growth stages. Transcripts for P2Y13 have been identified at stage E12 and ESTs for P2Y12 cloned from mouse embryos at stages E10.5, E14.5 and E16, suggesting that these two receptors may be involved in embryogenesis. Although these data seem contradictory, RT-PCR is a more sensitive technique than in situ hybridization and allows the detection of weakly expressed transcripts, whose expression may be below the detection level of the in situ hybridization technique. However, no ESTs have been cloned for P2X5 and P2Y14 during mouse embryogenesis (Table 3), although P2X5 channels are present in the developing rat skeletal muscle from E15 [30]. This would suggest either that there are differences of expression between the two rodent species, or that P2X5 is expressed in the developing mouse embryo at a later stage. Mouse P2X7 expression has been detected by in situ hybridization although no clear expression profile can be drawn, maybe due to weak expression or a ubiquitous signal [26]. No specific staining for P2X7 has also been observed in zebrafish embryos [28]. The staining evident at $24 \mathrm{hpf}$ was widespread, confirming the possible ubiquitous expression of this receptor during vertebrate embryogenesis.

\section{Ectonucleotidases}

Strikingly, the expression ATP-hydrolysing ectoenzymes is detected from very early phases of embryonic development. In Xenopus, Massé et al. carried out two comparative expression studies for the ENTPDase and ENPP family 
Table 2 Expression patterns of purinergic signalling components in rodents, Xenopus, zebrafish and chick embryos

\begin{tabular}{|c|c|c|c|}
\hline Gene & Detection methods & Expression domains & References \\
\hline \multicolumn{4}{|l|}{ Rodents } \\
\hline $\mathrm{A}_{1}$ & ISH (rat) & Heart, neural tissues, kidney & {$[98,99]$} \\
\hline $\mathrm{A}_{2 \mathrm{~A}}$ & ISH (mouse) & Neural tissues & {$[25]$} \\
\hline $\mathrm{A}_{2 \mathrm{~B}}$ & ISH (mouse) & Neural tissues & {$[25]$} \\
\hline $\mathrm{A}_{3}$ & ISH (mouse) & Aorta and heart & {$[57]$} \\
\hline P2X family & RT-PCR (rat) & Distinct expression profile in developing brain & {$[100]$} \\
\hline P2X family & RT-PCR (rat) & $\begin{array}{l}\mathrm{P} 2 \mathrm{X} 2,3,4 \text { and } 7 \text { in developing } \\
\text { inner ear tissues }\end{array}$ & {$[101]$} \\
\hline $\mathrm{P} 2 \mathrm{X} 1$ & $\begin{array}{l}\text { Immunostaining/ISH RT/PCR } \\
\text { (mouse) }\end{array}$ & In the pancreas, liver, gut, bladder and aorta & {$[26,102][103]$} \\
\hline $\mathrm{P} 2 \mathrm{X} 2$ & ISH (mouse) & Nervous system (brain and ganglia) & {$[26]$} \\
\hline $\mathrm{P} 2 \mathrm{X} 3$ & $\begin{array}{l}\text { Immunostaining (mouse) } \\
\text { Microarray/RTqPCR }\end{array}$ & $\begin{array}{l}\text { Neuronal (sensory ganglia) and non neuronal tissues } \\
\text { Higher in blastocysts than morula and 4-cell stages }\end{array}$ & {$[26,41,104][27]$} \\
\hline $\mathrm{P} 2 \mathrm{X} 2 / \mathrm{P} 2 \mathrm{X} 3$ & Immunostaining (rat) & $\begin{array}{l}\mathrm{P} 2 \mathrm{X} 3 \text { from E11, P2X2 from E14. In NS and non } \\
\text { neuronal tissues (kidney) }\end{array}$ & {$[105,106]$} \\
\hline $\mathrm{P} 2 \mathrm{X} 4$ & ISH (mouse) & Brain, nose, skin, muscle, skeleton & {$[25,26]$} \\
\hline $\mathrm{P} 2 \mathrm{X} 2,5$ and 6 & Immunostaining (rat) & In developing skeletal muscle tissues & {$[30]$} \\
\hline $\mathrm{P} 2 \times 7$ & Immunostaining (rat) & In developing pancreas & {$[107]$} \\
\hline $\mathrm{P} 2 \times 7$ & ISH (mouse) & No regional signal & {$[26]$} \\
\hline $\mathrm{P} 2 \mathrm{Y} 1$ & RT-PCR (mouse) & Entire embryo pool & [108] \\
\hline $\mathrm{P} 2 \mathrm{Y} 2$ & ISH (mouse) & No regional signal & {$[26]$} \\
\hline P2Y6 & ISH (mouse) & No regional signal & {$[26]$} \\
\hline ENTPD2 & ISH (mouse) & Ganglia and PNS & {$[26]$} \\
\hline ENTPD3 & ISH (mouse) & Wide expression & {$[26]$} \\
\hline ENPP1 & ISH (mouse) & Nervous system, Tooth & {$[25,26]$} \\
\hline ENPP2 & ISH (mouse) & Nervous system and various organ primordia & {$[25,33,34]$} \\
\hline $5^{\prime} \mathrm{NT}$ & ISH (mouse) & Mesenchyme & {$[26]$} \\
\hline TNAP & $\begin{array}{l}\text { RT-PCR/ISH/immunostaining/ } \\
\text { histochemical (mouse) }\end{array}$ & Early phases; brain precursor cells; skeleton & {$[26,109,110,111]$} \\
\hline EAP & RT-PCR & Restricted to early phases (until blastocyst) & {$[109,112]$} \\
\hline \multicolumn{4}{|l|}{ Xenopus } \\
\hline $\mathrm{A}_{1}$ & Electrophysiology, pharmacology & Spinal cord & [113] \\
\hline $\mathrm{A}_{2 \mathrm{~A}}$ & ISH & Somites and eyes. & [61] \\
\hline $\mathrm{P} 2 \mathrm{Y} 1$ & ISH/Northern blot & Brain, spinal cord, eyes, somites & {$[114]$} \\
\hline & RT-PCR & From cleavage stages. & $\begin{array}{l}\text { K. Massé and N. Dale, } \\
\text { unpublished data }\end{array}$ \\
\hline $\mathrm{P} 2 \mathrm{Y} 8$ & Northern blot/ISH & Neural tissue & {$[115]$} \\
\hline P2Y11 & RT-PCR/ISH & Mesoderm and derivatives, nervous system, placodes & [116] \\
\hline ENTPD family & RT-PCR/ISH & Distinct expression profile for ENTPD1,2 and 3 & {$[32]$} \\
\hline ENPP family & RT-PCR/ISH & Distinct expression profile for ENNP1, 2a, $2 \mathrm{~b}$ and 3 & {$[31]$} \\
\hline \multicolumn{4}{|l|}{ Zebrafish } \\
\hline $\mathrm{A}_{2 \mathrm{~A}, 2 \mathrm{~B}}$ & ISH & Distinct expression pattern; $2 \mathrm{~A}_{2}$ receptors & [29] \\
\hline $\mathrm{P} 2 \mathrm{X} 3$ & ISH & From 6-somite stages, Rohon beard neurons & {$[42]$} \\
\hline P2X family & ISH & $\begin{array}{l}\mathrm{P} 2 \mathrm{X} 1, \mathrm{P} 2 \mathrm{X} 3.1, \mathrm{P} 2 \mathrm{X} 3.2, \mathrm{P} 2 \mathrm{X} 4.2, \mathrm{P} 2 \mathrm{X} 8 \text { are expressed } \\
\text { but } \mathrm{P} 2 \mathrm{X} 5, \mathrm{P} 2 \mathrm{X} 7 \text { are not expressed in neural tissues. }\end{array}$ & {$[28]$} \\
\hline $\mathrm{P} 2 \mathrm{X} 3.1 / \mathrm{P} 2 \mathrm{X} 3.2$ & ISH & Restricted pattern in sensory neurons & {$[43]$} \\
\hline ENTPD3 & ISH & Brain and spinal cord (Rohon beard neurons) & {$[44]$} \\
\hline
\end{tabular}


Table 2 (continued)

\begin{tabular}{llll}
\hline Gene & Detection methods & Expression domains & References \\
\hline Chick & & & \\
$A_{1}$ & RTqPCR & In Hensen's node and heart primordia (HH4) & {$[60]$} \\
$\mathrm{A}_{3}$ & RT-PCR (adult) & Brain and muscle & {$[117]$} \\
P2X1 & Northern blot & Highest expression in lung, none in brain and eyes & {$[118]$} \\
P2X4 & RT-PCR & In brain and heart tissues, from day4 (HH23) & {$[119]$} \\
P2X5 & ISH/Northern blot & somites, heart, brain & {$[120]$} \\
P2X5/P2X6 & Immunostaining & Muscle and only P2X5 in nervous system & {$[121]$} \\
P2X5 & ISH/Northern blot & Nervous system, eye, heart, digestive tract and muscle & {$[122]$} \\
P2Y1 & Northern blot & spinal cord and muscle & {$[123]$} \\
& Northern blot/ISH & Mesoderm derivatives and CNS & {$[124]$} \\
ENPP2 & ISH & NS, somites, limb bud. & {$[34]$} \\
\hline
\end{tabular}

Gene duplication events have been described in Xenopus and zebrafish for enpp2 and the P2X family, giving rise to extra subtypes of these genes $I S H$ in situ hybridization, CNS central nervous system, PNS peripheral nervous system

members [31, 32]. Each member displays a distinct expression profile. ENTPD1, 2 and 3 are not maternal genes and their zygotic expression is switched on from either gastrulation or the end of neurulation. However ENPP1, 2a, 2b and 3 are all maternal suggesting that nucleotide hydrolysis

Table 3 Components of purinergic signalling that are not expressed at some or all stages of vertebrate embryogenesis

\begin{tabular}{|c|c|c|c|}
\hline Gene & Method & Stages & References/Websites \\
\hline \multicolumn{4}{|l|}{ Mouse } \\
\hline $\mathrm{A}_{3}$ & ISH & $\mathrm{E} 8.5, \mathrm{E} 12.5$ & {$[57]$} \\
\hline $\mathrm{P} 2 \mathrm{X} 5$ & ISH/EST & E14.5 & $\begin{array}{l}\text { [26] Eurexpress; } \\
\text { NCBI }\end{array}$ \\
\hline P2Y12 & ISH & E14.5 & [26] Eurexpress \\
\hline P2Y13 & ISH & E14.5 & [26] Eurexpress \\
\hline P2Y14 & ISH/EST & E14.5 & $\begin{array}{l}\text { [26] Eurexpress; } \\
\text { NCBI }\end{array}$ \\
\hline PAP & ISH & E14.5 & [26] Eurexpress \\
\hline \multicolumn{4}{|l|}{ Xenopus } \\
\hline ENTPD8 & RT/PCR & All stages & {$[32]$} \\
\hline ENTPD1,3 & RT/PCR & $\begin{array}{c}\text { Before end of } \\
\text { neurulation }\end{array}$ & {$[32]$} \\
\hline ENTPD2 & RT/PCR & Before gastrulation & {$[32]$} \\
\hline $\mathrm{P} 2 \mathrm{Y} 8$ & $\begin{array}{l}\text { Northern } \\
\text { blot }\end{array}$ & Before neurulation & {$[115]$} \\
\hline P2Y11 & RT/PCR & Before gastrulation & [116] \\
\hline \multicolumn{4}{|l|}{ Zebrafish } \\
\hline $\mathrm{P} 2 \mathrm{X} 2, \mathrm{P} 2 \mathrm{X} 4.1$ & ISH & 24 and $48 \mathrm{hpf}$ & {$[28]$} \\
\hline ENTPD3 & ISH & Before $23 \mathrm{hpf}$ & {$[44]$} \\
\hline \multicolumn{4}{|l|}{ Chick } \\
\hline $\mathrm{P} 2 \mathrm{X} 5$ & ISH & At stage HH11 & {$[120]$} \\
\hline
\end{tabular}

can occur during the early phases of development. In mouse embryos, only the ENPP2 expression profile has been reported in detail $[33,34]$. ESTs for several murine enzymes have been identified at the zygote stage (ENTPD2 and ENPP2) and in the blastocyst stage (ENTPD1, ENPP1, ENPP3). Recent evidence suggests that the role of ENPP2 or autotaxin protein during vertebrate physiology and embryogenesis may be more related to its ability to generate bioactive lipids, such as LPA, than to its activity in hydrolyzing ATP [35]. Not many studies report the expression of ectonucleotidases in chick embryos, but ESTs have been identified for ENTPD1, ENTPD2, ENPP1 and CD73.

There are few reports on the expression of the CD73 (or $5^{\prime} \mathrm{NT}$ ) enzyme at embryonic stages. EST counts on the NCBI website and in situ hybridization [26] suggest expression during organogenesis. This is quite interesting considering that increased levels of adenosine signalling during cleavage can be lethal [36], suggesting that vertebrate embryos may limit adenosine production during the very earliest phases of embryogenesis. However, this role of 5 NT could conceivably be fulfilled by other enzymes such as the alkaline phosphatases, which are also expressed during mammalian embryogenesis. The embryonic alkaline phosphatase (EAP) predominates during the very early phases of development, whereas tissue non-specific alkaline phosphatases (TNAP) predominate after implantation stages. Prostatic acid phosphatase (PAP) [37, 38] is also potentially relevant as it is widely expressed in adult non-prostatic tissues, in particular in adult rat and in mouse nociceptive dorsal root ganglia (DRG) neurons [39, 40]. No study has yet investigated systematically the expression profiles of these enzymes during embryonic development but transcripts have been described in early phases of vertebrate development: oocyte, zygote and cleavage stages for mouse embryos; and neurula stages for Xenopus embryos. However, 
in situ hybridization failed to detect mouse PAP transcripts at later phases [26].

\section{Emergent common principles}

Although most of these genes are expressed in the neural tissues and sensory organs, expression has also been reported in somites and muscle tissues, heart, kidney and gastrointestinal organs (Table 2). This demonstrates that purinergic signalling may be involved in the formation of all three germ layer derivatives (ectoderm, mesoderm and endoderm).

As the expression studies of the purinergic components across the four model organisms are incomplete, it is difficult to abstract general principles of expression during embryogenesis. However, some common principles can be outlined. ENTPD8 seems to be the only ectonucleotidase that is not expressed during mouse embryogenesis as no ESTs have been identified for this gene during these developmental stages. Moreover, no ESTs for this gene have been cloned during chick, rat, human and zebrafish embryogenesis and it is not expressed during Xenopus embryogenesis [32].

The P2X3 receptor is expressed in DRG in mouse [41] and Rohon beard neurons in zebrafish, which display functional homology to mammalian DRG neurons [28, 42, 43], suggesting a conserved role for this receptor during evolution. However, major differences can also be noted. For example, murine ENTPDase3 displays a wide expression profile at E14.5 [26] that differs from the tissue-restricted expression seen in spinal cord of zebrafish and Xenopus embryos [32, 44].

Further work is needed to generate more comprehensive comparative expression profiles for each of these receptors and enzymes that document expression of these components at specific tissues and developmental stages. This is a necessary step for in vivo functional studies and ultimately for a better understanding of purine roles during embryogenesis.

\section{Analysis of purinergic mechanisms in development}

Establishing a causal link between purinergic signalling and development depends on far more than determination of expression patterns. Demonstration of causality requires perturbation of some aspect of purinergic signalling and analysis of resultant phenotype. This can be accomplished via genetic or pharmacological methods. Genetic methods include constitutive and inducible gene knock-out or overexpression. The use of siRNA and antisense oligonucleotides, such as morpholino oligonucleotides (MO) is also possible with frog and zebrafish embryos. Pharmacological methods have the advantage of simplicity and rapidity. However, highly selective agents that target specific components of purinergic signalling are not always available, and application of these agents to the correct stages of development and organs/tissues may be problematic.

Genetic manipulations in mice

A number transgenic knock-out mice lacking expression of particular receptors and enzymes have been generated (Table 4). For the most part, these mice have not been generated for the specific purpose of analysis of development. Rather, these mice have been made to allow analysis of physiological function in the adult. This means that detailed data on the effect of these knock-outs on development is not necessarily available. Nevertheless, a striking and perhaps puzzling observation is that the majority of receptor-mutant mice are viable, fertile and do not display any gross morphological abnormality.

The phenotypes of these single mutant mice are usually confined to a small subset of tissues, with studies mostly focusing so far on the physiology of the nervous, the excretory or hematopoietic systems. The absence of any reported developmental phenotypes for single gene mutations might, at first sight, suggest that purinergic signalling does not play an essential role during embryogenesis. Nevertheless, these are mainly constitutive mutations and the possibility of compensatory changes in the expression of other genes to rescue normal development remains plausible. Furthermore, the majority of the studies have not investigated whether morphological defects occur during embryonic life.

One proxy of whether embryonic development is affected is to analyze whether the percentage of homozygous mice born is similar to the expected Mendelian rate. For some strains e.g. P2 $\mathrm{Y}^{-/-}$or $\mathrm{P} 2 \mathrm{X} 2^{-/-}$the number of knock-out mice born was significantly lower than expected $[45,46]$, suggesting a possible in utero death for the homozygous mice.

There are seven P2X receptor subunits. Thus, loss of one receptor subunit could plausibly be compensated by overexpression of another of similar functionality. Double gene knock-outs can partly address this possibility. For example, double P2X2/P2X3 KO mice exhibit 90\% lethality with major organ abnormalities, such as enlarged hearts, marked atrophy of lymphohaematopoietic organs [46]. These phenotypes were not observed in single P2X2 and P2X3 mutants $[46,47]$. This possibility is even more plausible where physiologically active heteromeric receptors exist. For example, the P2X2 subunit can be incorporated into heterotrimers with $\mathrm{P} 2 \mathrm{X} 3$ subunit [48]. If one of the subunits is deleted, it could be replaced functionally by a homomeric receptor. This may explain why the knock-out of both P2X2 and P2X3 subunits has a far greater phenotype and lethality than deletion of either subunit individually.

It is also important to note that the loss of one given specific receptor does not necessarily induce the up-regulation of expression of the related receptors. For example, deletion of 
Table 4 Phenotypes of mutants with disrupted purinergic signalling

\begin{tabular}{|c|c|c|c|}
\hline Gene & Studies & Phenotype & References \\
\hline \multicolumn{4}{|l|}{ Mouse } \\
\hline $\mathrm{A}_{1} \mathrm{KO}$ & Behavioural/Physiological & Increase of aggressiveness; defects in TGF & {$[20,125]$} \\
\hline $\mathrm{A}_{2 \mathrm{~A}} \mathrm{KO}$ & Behavioural/Physiological/histological & $\begin{array}{l}\text { Increase of aggressiveness and blood pressure; } \\
\text { Neuroprotection, No neuronal developmental defects }\end{array}$ & {$[126,127]$} \\
\hline $\mathrm{A}_{2 \mathrm{~B}} \mathrm{KO}$ & Physiological & Inflammation responses & {$[23,128]$} \\
\hline $\mathrm{A}_{3} \mathrm{KO}$ & Physiological & Defects in inflammatory responses. & [49] \\
\hline $\mathrm{P} 2 \mathrm{X} 1 \mathrm{KO}$ & Physiological & Male infertility & [19] \\
\hline $\mathrm{P} 2 \mathrm{X} 2 \mathrm{KO}$ & Physiological/Behavioural/ & No gross phenotype & {$[46]$} \\
\hline $\mathrm{P} 2 \mathrm{X} 3 \mathrm{KO}$ & $\begin{array}{l}\text { Physiological } \\
\text { Behavioural }\end{array}$ & Defects in pain responses and bladder function & {$[18,47]$} \\
\hline $\mathrm{P} 2 \mathrm{X} 2 / \mathrm{P} 2 \mathrm{X} 3 \mathrm{KO}$ & Physiological/behavioural & Lethal (at P7) and defects in sensory response & {$[46]$} \\
\hline $\mathrm{P} 2 \mathrm{X} 4 \mathrm{KO}$ & Physiological & $\begin{array}{l}\text { Defects in vascular tone and remodelling; Defects } \\
\text { in synaptic potentiation; involvement in recruited } \\
\text { macrophages }\end{array}$ & {$[21,22,129]$} \\
\hline $\mathrm{P} 2 \mathrm{X} 7 \mathrm{KO}$ & Physiological & Defects in cytokine production, in pain response & {$[130,131]$} \\
\hline $\mathrm{P} 2 \mathrm{Y} 1 \mathrm{KO}$ & Physiological & Defects in platelet aggregation and thrombosis & {$[52,53]$} \\
\hline $\mathrm{P} 2 \mathrm{Y} 2 \mathrm{KO}$ & Physiological (isolated cells or organs) & Defects in calcium and chloride transport & {$[132,133]$} \\
\hline $\mathrm{P} 2 \mathrm{Y} 4 \mathrm{KO}$ & Physiological (isolated organs) & Defects in chloride transport & {$[45]$} \\
\hline $\mathrm{P} 2 \mathrm{Y} 6 \mathrm{KO}$ & $\begin{array}{l}\text { Physiological (isolated cells and } \\
\text { trachea) }\end{array}$ & $\begin{array}{l}\text { Defects in UDP response in macrophages, } \\
\text { VSM and endothelial cells. }\end{array}$ & {$[134]$} \\
\hline $\mathrm{P} 2 \mathrm{Y} 12 \mathrm{KO}$ & Physiological & Defects in platelet thrombosis & {$[135,136]$} \\
\hline $\mathrm{P} 2 \mathrm{Y} 13 \mathrm{KO}$ & Physiological & Defects in cholesterol metabolism & {$[137]$} \\
\hline $\mathrm{P} 2 \mathrm{Y} 14 \mathrm{KO}$ & Physiological & Defects in stomach muscle contractility & {$[24]$} \\
\hline ENTPD1 KO & Physiological & Defects in hemostasis and thromboregulation & [138] \\
\hline $5^{\prime}-\mathrm{NT}$ KO & $\begin{array}{l}\text { Physiological (in vivo and isolated } \\
\text { cells or nephrons) }\end{array}$ & Defects in TGF & {$[139,140]$} \\
\hline ENPP1 & ENU mutagenesis & Defects in mineralization and calcification & {$[141]$} \\
\hline ENPP1 & Spontaneous mutation & Defects in ossification & {$[142]$} \\
\hline ENPP2 KO & Developmental & $\begin{array}{l}\text { Lethal (E9.5), defects in neural system and } \\
\text { vascular development }\end{array}$ & {$[143,144]$} \\
\hline PAP KO & Physiological & Increase of nociceptive responses & {$[37]$} \\
\hline TNAP KO & Developmental & $\begin{array}{l}\text { Lethal(before weaning) Defects in bone } \\
\text { mineralization and neural tube abnormalities }\end{array}$ & {$[145]$} \\
\hline EAP KO & Developmental & $\begin{array}{l}\text { Delay in development; blastocyst degeneration; } \\
\text { reduction in litter size }\end{array}$ & {$[146]$} \\
\hline $\mathrm{A}_{1} \mathrm{KI}$ (cardiac promoter) & Physiological & $\begin{array}{l}\text { Lethal (between } 6 \text { and } 12 \text { weeks) congestive } \\
\text { heart failure }\end{array}$ & {$[56]$} \\
\hline $\mathrm{A}_{3} \mathrm{KI}$ (muscle promoter) & Histological & Lethal (before E8.5) & {$[57]$} \\
\hline Adenosine & In vitro culture & Blocks development at the 2-cell stage. & {$[36]$} \\
\hline \multicolumn{4}{|l|}{ Xenopus } \\
\hline MO ENTPD2 & Developmental & Loss of eye & {$[51]$} \\
\hline \multicolumn{4}{|l|}{$\mathrm{MO} \mathrm{P} 2 \mathrm{Y}_{1}$} \\
\hline P1 receptor agonists & Developmental & $\begin{array}{l}\text { Defects in somite formation; reduction of } \\
\text { myoD expression }\end{array}$ & {$[61]$} \\
\hline $\mathrm{P} 1$ receptor antagonists & Pharmacological screen & Defects in angiogenesis and lymphangiogenesis & {$[147]$} \\
\hline $\mathrm{P} 2$ receptor antagonists & Developmental & $\begin{array}{l}\text { Defects in gastrulation, formation of } \\
\text { ventralized embryos }\end{array}$ & {$[148]$} \\
\hline \multicolumn{4}{|l|}{ Zebrafish } \\
\hline $\mathrm{MO} 2 \mathrm{X}_{3.1}$ & Developmental & $\begin{array}{l}\text { Defects in craniofacial development and } \\
\text { sensory circuit formation }\end{array}$ & {$[55]$} \\
\hline
\end{tabular}


Table 4 (continued)

\begin{tabular}{|c|c|c|c|}
\hline Gene & Studies & Phenotype & References \\
\hline \multicolumn{4}{|l|}{ Chick } \\
\hline P1 receptor agonists & Developmental & Defects in heart looping & {$[60]$} \\
\hline Adenosine & Physiological & Defects in vascular development & [59] \\
\hline \multicolumn{4}{|l|}{ Other organisms } \\
\hline \multicolumn{4}{|l|}{ Starfish } \\
\hline Adenosine & Developmental & Blocks development at the 256-cell stage. & {$[58]$} \\
\hline \multicolumn{4}{|l|}{ Dictyostelium } \\
\hline Quintuple dP2X KO & & Disruption of intracellular calcium signalling & [149] \\
\hline $\mathrm{dP} 2 \mathrm{X} \mathrm{KO}$ & & Defects of osmoregulation & {$[150]$} \\
\hline
\end{tabular}

For mouse, only papers referring to mouse transgenic generation are listed

$K O$ knock-out, $K I$ knock-in, $M O$ morpholino antisense oligonucleotide knock down of expression, $T G F$ tubuloglomerular feedback, $V S M$ vascular smooth muscle

the $\mathrm{A}_{3}$ receptor gene does not induce changes of expression of $A_{1}, A_{2 A}$ or $A_{2 B}$ receptors in mice [49]. Furthermore, the loss of $A_{2 B}$ or $\mathrm{P} 2 \mathrm{X} 3$ receptor subunits does not alter expression of other adenosine or $\mathrm{P} 2 \mathrm{X}$ receptors $[18,50]$.

\section{Lower vertebrates}

Xenopus and zebrafish have the great advantage of allowing easy access to very early developmental stages. In both of these models, there is the possibility of combinatorial microinjections of mRNAs, proteins and MO allowing gain and loss of function making them advantageous models to decipher the complexity of the purinergic signalling pathway. Moreover, targeted injections are possible in Xenopus, enabling to target one specific tissue or organ allowing study of gene function in vivo when mis-expression in the whole embryo is lethal.

Massé et al. demonstrated that ADP controls eye formation by regulating the expression of the eye field transcription factor (EFTF) gene network at stage 12.5, just following the end of gastrulation [51]. It is worth pointing out that the effects due to P2Y1 mis-expression were mild and could have been unnoticed without careful experimental design and measurement. In these experiments, gene manipulation was unilateral thus giving internal controls (nonmanipulated side) for comparison in each embryo. Equally mis-expression of ENTPDase2 while giving much greater phenotypes than mis-expression of the P2Y1 receptor was unable to prevent eye formation. By contrast, simultaneous knockdown of the P2Y1 receptor and ENTPDase2 completely ablated eye formation. This may be an important general message for the analysis of purinergic signalling in development: combinatorial deletion or knockdown of functionally linked components may be essential to uncover phenotype and hence developmental roles.
So far, there is no evidence that a similar purinergic mechanism for eye development pertains to mouse. $\mathrm{P} 2 \mathrm{Y}^{-/-}$newborn mice have eyes [52, 53], as do mice lacking ENTPDase2 (unpublished observation, Kristine Gampe, Herbert Zimmermann, Simon C. Robson). However the expression of these components should be studied from the start of the neurulation, as early as stage E7.5. This is because murine Pax6 (a key EFTF gene) is first detected at stage E8 in the head neural ectoderm, including the optic pit, the first morphologically detectable indication of the eye region [54]. By analogy with Xenopus, it may also be necessary to perform combinatorial deletions of P2Y1 and ENPTDase2 to uncover a major eye phenotype in mouse.

Further evidence for the role of ATP signalling in lower vertebrate development comes from the knockdown of P2X3 receptor in zebrafish. This leads to defects in craniofacial development and sensory circuit formation [55]. However, no such phenotype is observed in $\mathrm{P}_{2} \mathrm{X}^{-/-}$mice $[18,46]$. It is possible that the two genes do not fill the same functions in the two organisms. Nevertheless, as these genes display the same expression profile in zebrafish and mouse, we think it likely that the discrepancy between these phenotypes may be due to one of the reasons discussed above.

\section{Adenosine signalling and development}

In contrast to the apparent tolerance of development to alteration of $\mathrm{P} 2$ receptors and even deletion of single ectonucleotidases, a striking observation is that modification of adenosinergic signalling can have powerful effects on development. The overexpression of the adenosine $A_{1}$ receptor under the control of a cardiac promoter is lethal postnatally due to defects in the heart [56]. Perhaps more interesting developmentally is the overexpression of the $\mathrm{A}_{3}$ receptor under the control of a muscle promoter [57]. This is lethal 
by E8.5. Application of exogenous adenosine blocks mouse and starfish development during the cleavage phase [36, 58]. Furthermore, exogenous adenosine receptor agonists induce several developmental defects in Xenopus and chick [59-61]. The lack of major phenotypes in $5^{\prime} \mathrm{NT}$ KO mice might be explained by the existence of other enzymes able to generate adenosine from AMP. Interestingly, $\mathrm{KO}$ mutant mice for EAP and TNAP display developmental phenotypes (Table 4).

Adenosine deaminase (ADA) is a potentially important mechanism for the removal of adenosine through conversion to inosine. During mouse embryogenesis, expression of ADA is not detected in the embryo before E7, although ADA activity is detected in the placenta [62]. Expression levels of ADA increase during E7 and E9 in the mouse embryo. From E15, ADA is expressed in the thymus, spleen, gut and kidney [63]. $\mathrm{ADA}^{-/-}$mice die perinatally at E19 [64, 65]. ADA-deficient patients suffer from severe immunodeficiency but also display several neurological abnormalities [66]. However, this neurological phenotype could also be explained by a non-enzymatic function of the ectoADA, which by binding to the $A_{1}$ receptor and the CD26 protein, could be involved in cell-cell interactions [67].

\section{Purinergic signalling and development - a new synthesis}

So far, with one or two exceptions, manipulation of purinergic signalling (at least of single signalling components) has surprisingly small effects on development. One reason for this might be that these mechanisms simply are not important for development. Nevertheless, the developmentally specific expression of key components that for some is present and similar in each of the four model systems suggests to us that such an absolutist position is not easily tenable. Instead, we wish to explore whether there are deeper mechanistic reasons as to why the role of purinergic signalling has not yet been convincingly established more generally.

Morphogenetic gradients and chemical signalling during development

Despite the complexity of elaborating an organism from a single cell, rather few signalling pathways seem to be involved in embryogenesis. In effect, the embryo possesses a small 'tool kit' and uses the same factors repeatedly at different times and locations during embryogenesis. Some of these signalling molecules are morphogens-defined as molecules that can act directly on cells to produce specific responses (usually activation of target genes) that depend on morphogen concentration [68]. The key point is that morphogens diffuse from their source to produce a concentration gradient that encodes position. Cells read their position within this concentration gradient and determine their developmental fate accordingly.

The Notch signalling pathway acts via the activation of the Notch receptor by membrane-bound ligands that are members of the Delta or Serrate families [69]. However, the majority of the morphogens are soluble proteins, which can be grouped into a few families based on their structures. The major families are the hedgehog family, the fibroblast growth factors family, the wingless (or Wnt) family and the transforming growth factor (TGF)- $\beta$ superfamily, which includes, among other proteins, the TGF- $\beta$ family, the activin family, the bone morphogenetic proteins and the nodal and nodal-related proteins [70-73].

The specificity of the functions of each member of these families is due to their expression pattern and the availability of their specific receptors. It can be seen from this that both the mechanism of producing the morphogen and expression of the receptors for the morphogen are critical to correct operation of this signalling mechanism.

RA is a non-protein morphogen derived from vitamin A or retinol and is responsible for all of the biological activity associated with this vitamin. During development, RA is involved in somitogenesis as well as central nervous system patterning and neuronal differentiation [74]. These actions are mediated by heterodimers of two nuclear receptors, the retinoic acid receptors (or RARs) and retinoid X receptors (RXR), although the RA-binding specificity relies on the RAR receptors [75]. These heterodimers bind to the RARE DNA sequences and can activate for example the transcription of homeobox-containing genes.

The various morphogenetic signalling systems do not act in isolation but instead interact with each other to construct the different organs during vertebrate development, as for example during the development of the vertebrate limb [76]. We now consider the extent to which the purines can be considered as morphogens.

Evidence supporting the purines as morphogens

Several criteria need to be satisfied for a substance to be considered as a morphogen. Firstly, the molecule should be present at the right place and time and must be released from a localized source to allow formation of a concentration gradient. The available evidence suggests that the purines meet this criterion. In vivo measurements using specific biosensors have demonstrated in Xenopus that ATP is indeed specifically released in the anterior neural plate but not in the posterior neural plate, just before eye field specification [51]. ATP, ADP and adenosine gradients would therefore be shaped and generated by the activity of the ectonucleotidases (see also Fig. 3 below).

Secondly, gene expression should depend upon morphogen concentration. The morphogen gradient will thus control 


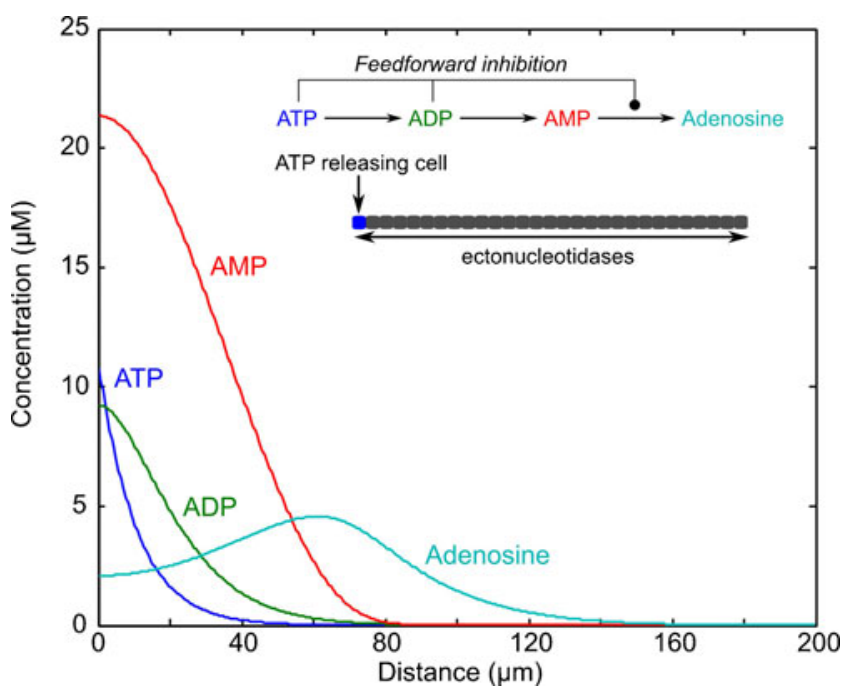

Fig. 3 Simulation of diffusion and metabolism of ATP - a complex purinergic morphogenetic field. The simulation (values shown at $T=5 \mathrm{~s}$ after beginning) shows that ATP and ADP are locally high in concentration over the first $30-40 \mu \mathrm{m}$, but that adenosine peaks at around $60 \mu \mathrm{m}$ and remains high in concentration up to around $120 \mu \mathrm{m}$. Thus a complex pattern is produced where the potential for ATP/ADP actions is bounded and limited by a zone where adenosinergic actions have the potential to predominate. The simulation considers a short strip of cells (inset) where one cell at the end releases ATP; the ATP is then converted successively through the intervening intermediates to adenosine, with feed-forward inhibition of the final step mediated by ATP and ADP (inset top). All the metabolites diffuse along the strip with the same diffusion coefficient $\left(300 \mu \mathrm{m}^{2} / \mathrm{s}\right)$. The conversion of ATP and metabolites are described by Michaelis-Menten kinetics, based on literature values [93-95]: ATP, $\mathrm{K}_{\mathrm{m}} 33.3 \mu \mathrm{M}, \mathrm{V}_{\max }, 100 \mu \mathrm{M} / \mathrm{s}$; ADP, $\mathrm{K}_{\mathrm{m}} 9.5 \mu \mathrm{M}, \mathrm{V}_{\max } 20 \mu \mathrm{M} / \mathrm{s}$; AMP, $\mathrm{K}_{\mathrm{m}} 0.94 \mu \mathrm{M}, \mathrm{V}_{\max }, 20 \mu \mathrm{M} / \mathrm{s}$; both ATP and ADP inhibit the conversion of AMP to adenosine (Ado) with a $\mathrm{k}_{\mathrm{i}}$ of $0.1 \mu \mathrm{M}$. The simulation is based on the following parallel linked equations: $\partial[\mathrm{ATP}] / \partial \mathrm{t}=\mathrm{D} \partial^{2}[\mathrm{ATP}] / \partial x^{2}-\mathrm{k}_{1}[\mathrm{ATP}] ; \partial[\mathrm{ADP}] / \partial \mathrm{t}=\mathrm{D}$ $\partial^{2}[\mathrm{ADP}] / \partial x^{2}+\mathrm{k}_{1}[\mathrm{ATP}]-\mathrm{k}_{2}[\mathrm{ADP}] ; \partial[\mathrm{AMP}] / \partial \mathrm{t}=\mathrm{D} \partial^{2}[\mathrm{AMP}] / \partial x^{2}+$ $\mathrm{k}_{2}[\mathrm{ADP}]-\mathrm{k}_{3} \cdot \mathrm{k}_{\mathrm{i}}[\mathrm{AMP}]$; and $\partial[$ Ado $] / \partial \mathrm{t}=\mathrm{D} \partial^{2}[$ Ado $] / \partial x^{2}+\mathrm{k}_{3} \cdot \mathrm{k}_{\mathrm{i}}[$ AMP $]$. Where $\mathrm{D}$ is the diffusion coefficient, and $\mathrm{k}_{1}, \mathrm{k}_{2}$ and $\mathrm{k}_{3}$ are rates based on the Michaelis-Menten kinetics given above. These equations were solved numerically using code written for Matlab. We thank Dr. Magnus Richardson for assisting us with this code

patterns of gene expression and hence cell fate. In Xenopus the increase of extracellular ADP (by overexpression of ENTPDase2) induced ectopic Pax6 expression and ectopic eyes [51]. By contrast, a reduction of ADP (by knockdown of ENTPDase2 or overexpression of ENTPDase1) reduced Pax6 expression in the eye field and can prevent eye formation [51]. Therefore, ADP at least meets the second of these criteria. More generally as there are many different receptor subtypes for ATP, ADP and adenosine each having different affinities for their respective agonists, it is plausible that they could mediate concentration-dependent cell-specific actions.

Finally, the actions of a morphogen should be direct (i.e. cell autonomous). No studies have yet demonstrated direct induction of gene expression via activation of purinergic receptors in a developmental context. This is a key outstanding issue for the definitive classification of purines as morphogens: can purinergic receptors directly alter gene expression in a concentration dependent manner during development and if so, what signalling pathways mediate this action? An intriguing possibility is that mobilization of intracellular $\mathrm{Ca}^{2+}$ via the activation of purinergic receptors (such as P2Y1) could mediate changes in gene expression and also act to link the purinergic pathways with those of other established morphogens such as Wnt which has an established $\mathrm{Ca}^{2+}$-sensitivity [71]. However, there are precedents for purinergic receptors acting on other pathways involved in the regulation of gene expression. For example, several purinergic receptors can alter the activity and expression of the transcription factor NFKB [77-82]. Activation of both adenosine and ATP receptors will induce phosphorylation of the CREB, a key step in its activation and ability to bind to the cAMP response element, and thus also have the potential to alter gene expression via this pathway [83-86].

As they meet two of the three essential criteria, we propose purines as putative morphogens. Whether they meet the third criterion has not yet been estabished or refuted.

\section{Parallels between RA and purinergic pathways}

The most similar established morphogen to the purines is RA (like the purines it is a low molecular weight diffusible molecule) and we shall therefore explore this signalling system further.

The availability of the bioactive RA is controlled by specific enzymes allowing its synthesis and degradation. RA is synthetized from retinol in two steps of oxidation, each catalyzed by different families of enzymes. The first step is the reversible and rate limiting conversion of retinol to retinal by an alcohol dehydrogenase and short-chain dehydrogenase/reductase of which retinol dehydrogenase 10 (RDH10) is the most important during development [87]. The second step is the irreversible oxidation of retinal to RA by enzymes of the aldehyde dehydrogenase family also known as retinal dehydrogenase (RALDH).

During development, RALDH2 is considered to be the predominant enzyme and responsible for the production of nearly all embryonic RA [88]. RA is then degraded into a wide variety of oxidized metabolites, such as 4-oxo-RA or 4-HO-RA. The Cyp26 family controls the catabolism of RA. Although some studies have suggested potential biological functions for these downstream metabolites, the principal role of Cyp26 proteins is to degrade RA and therefore terminate RA-induced effects. This places Cyp26 and the metabolic enzymes of RA as the major regulators of the RA signalling pathway by restricting its availability and establishing strictly controlled domains of RA distribution in order for embryonic development to properly occur (reviewed in [89]). Therefore, the concept of RA acting as 
a morphogen during development has been extended to encompass Cyp26 as the main constraint for defining areas of RA-induced gene expression [90].

The importance of RA-metabolising enzymes during embryogenesis has been demonstrated by generation of $\mathrm{KO}$ mice for these enzymes. Mice lacking RDH10, RALDH2 or Cyp26a die during embryonic life and exhibit severe patterning defects and morphological abnormalities [87, 88, 91]. Surprisingly, null mutants for the RA receptors $\operatorname{RAR} \alpha, \operatorname{RAR} \beta, \operatorname{RAR} \gamma$ remain viable and the observed abnormalities are restricted to a subset of tissues (reviewed in [92]). However, in utero lethality and severe developmental defects are observed in double RAR transgenic mice revealing an extensive functional redundancy within the members of each family. This is not surprising considering the existence of several RA receptor isoforms, the various tissues combinations of RAR/RXR expression during embryogenesis. It should be remembered however that RAR/ RXR alter gene expression by binding directly to specific DNA sequences. The purinoreceptors if they do indeed directly regulate gene expression during embryogenesis would have to achieve this via second messenger pathways.

Striking parallels can thus be drawn between the RA and purinergic signalling pathways. Both of them are characterized by: (1) the activation of multiple receptor subtypes and potential receptor redundancy; and (2) the control of the availability of the bioactive molecules by catabolizing enzymes which exhibit developmentally selective expression. In both cases, it seems necessary to delete more than one receptor subtype to observe major developmental defects. And in both, deletions of single degradative enzymes seem to give more profound phenotypes than deletion of single receptors.

However, the purinergic system offers potential for greater complexity of morphogenetic signalling than does the RA system. This is because the ectonucleotidases that terminate the effects of ATP-induced effects also initiate the effects of the downstream molecules, ADP and adenosine, via the inactive precursor, AMP.

Unique features of purines as putative morphogens

The kinetics of the ectonucleotidases are complex and suggest interesting possibilities for the formation of morphogenetic fields by purines. For example, it is well known that the ecto-5' nucleotidase (5'-NT) undergoes feed-forward inhibition by ADP and ATP [93]. This has previously been proposed to provide temporal separation between the release of ATP and the appearance of adenosine [94, 95]. This temporal separation is functionally possible because one of the intermediates on the way to adenosine, AMP has no action at either $\mathrm{P} 1$ or $\mathrm{P} 2$ receptors. Thus AMP can act as an inactive store for the delayed production of adenosine.
It occurred to us that the same mechanisms would also provide spatial separation between the release of ATP and the production of extracellular adenosine. Consider a simple model with a linear row of cells with a cell at one end of this row releasing ATP (Fig. 3, inset). The ATP will diffuse along the row of cells dropping in concentration with distance from the source. If the ectoATPases and ecto- $5^{\prime} \mathrm{NT}$ are uniformly distributed, then close to the source of the ATP, the final step in the production of adenosine from AMP would be rather slow as a result of the feed-forward inhibition of ecto- $5^{\prime} \mathrm{NT}$. With increasing distance from the site of release the concentrations of ATP and ADP will decrease (by diffusion) allowing the enzymatic production of adenosine to increase in rate. The inactive AMP will have accumulated and hence provide a reservoir production of adenosine at some distance from the original source of ATP. Furthermore, as it is not taken up, AMP has the potential to diffuse further in the tissue prior to breakdown to adenosine, than adenosine itself which will be removed from the extracellular space by a variety of concentrative and equilibrative transporters.

We have performed some elementary simulations (Fig. 3) to illustrate this idea and confirm that with minimal assumptions, the known properties of the components of purinergic signalling lead to a spatial patterning of ATP and adenosine levels that is considerably more complex than that afforded by the RA pathway (which would give a pattern roughly similar to that of ATP alone).

While our ideas are purely speculative, they do have three implications. Firstly, they may provide an explanation as to why alterations of receptor expression by themselves may not be very efficacious in altering development- the morphogenetic pattern still remains and can be read by other related receptors, perhaps with lower efficiency but still well enough to control development. Secondly, they provide a reason why mis-expression of the ectonucleotidases may be more effective in altering development as they will change the extent and shape of the hypothesized purinergic morphogenetic field. Finally, they provide a way to understand why overexpression of adenosine receptors and indeed exogenous adenosine have the tendency to be lethal-these manipulations by either changing the levels of adenosine globally, or by altering the sensitivity of adenosine detection may obscure the extent and shape of the hypothesized purinergic morphogenetic field.

Temporally defined signalling

Much of the thinking on morphogenetic fields considers steady-state solutions to the equations governing diffusion of the morphogens. In this limiting case, the concentration of morphogen reaches a spatial distribution that does not vary with time, i.e. $\partial \mathrm{c} / \partial \mathrm{t}=\mathrm{D} \partial^{2} \mathrm{c} / \partial x^{2}=0$. 
Given that development is rather slow compared to the release and diffusion of small molecules such a simplifying assumption of time-invariant fields is probably justified in many cases. However, our studies on the development of the eye in Xenopus suggest that rather rapid signalling may also be relevant. We observed a brief event of ATP release at a time and location appropriate to trigger the activation of the eye field transcription factor network. That this brief signalling event resulted in sustained gene activation comes down to the characteristics of the gene network and feedback activation present within the EFTFs. It is unlikely that this is unique to the EFTFs; transient ATP signalling could be important in other contexts. It is worth reiterating that even in the context of transient ATP release, diffusion of ATP away from the source will conform to the diffusion equation and the enzymatic kinetics illustrated in Fig. 3. It is therefore highly likely that a point source of ATP release will be surrounded by an annulus of adenosine production. If ATP and adenosine were to have opposing actions on gene induction, such an arrangement might give spatially very precise gene activation.

\section{Concluding remarks}

We think that there are several new steps that should be taken in the analysis of purinergic signalling in early development. The first and simplest is that far more comprehensive data on expression patterns needs to be compiled. As can be seen from our summaries in Tables 2 and 3, the coverage of expression during development is incomplete, making it hard to draw general conclusions with regard to patterns common to the four models and to identify the key groups of developmentally important signalling molecules. Furthermore, the specificity of expression at a cellular level in the developing embryo should also be documented. This step would allow technical approaches that ameliorate the difficulty of studying early development in mouse embryos. For example targeted, cell-specific, deletion of purinergic signalling components mediated via cre-recombinase expression driven by promoters expressed in the correct cell types and at the correct developmental stages may enable much better tests of the roles of purinergic signalling in development.

Secondly, we suggest that our hypothesis of complex purinergic morphogenetic fields should be more thoroughly tested. The key feature of our hypothesis is that there should be spatial separation between ATP release and adenosine accumulation. Although electrochemical biosensing methods for the purines exist [96], perhaps the best way to investigate this would be with imaging methods as these afford the possibility of two-dimensional spatial mapping of analyte concentration with time. The luciferase technique provides a way of imaging ATP; however, an equivalent imaging method for adenosine has yet not been devised.
One promising avenue might be to develop FRET-based biosensors for adenosine [97] utilizing heterologous expression of adenosine receptors, although these receptors themselves may perturb development if they remain functional.

Finally, as different morphogenetic systems interact, it would be interesting to see whether purinergic signalling also influences the properties of established morphogenetic signalling pathways such as Wnt, hedgehog and RA.

Acknowledgements We thank the Wellcome Trust and Association Française contre les Myopathies (AFM) for support and Dr Magnus Richardson for assistance with numerical simulations.

Open Access This article is distributed under the terms of the Creative Commons Attribution Noncommercial License which permits any noncommercial use, distribution, and reproduction in any medium, provided the original author(s) and source are credited.

\section{References}

1. Burnstock G (1997) The past, present and future of purine nucleotides as signalling molecules. Neuropharmacology 36:1127-1139

2. Abbracchio MP, Burnstock G, Verkhratsky A, Zimmermann H (2009) Purinergic signalling in the nervous system: an overview. Trends Neurosci 32:19-29

3. Khakh BS, Burnstock G, Kennedy C, King BF, North RA, Seguela P, Voigt M, Humphrey PP (2001) International union of pharmacology. XXIV. Current status of the nomenclature and properties of P2X receptors and their subunits. Pharmacol Rev 53:107-118

4. Abbracchio MP, Burnstock G, Boeynaems JM, Barnard EA, Boyer JL, Kennedy C, Knight GE, Fumagalli M, Gachet C, Jacobson KA, Weisman GA (2006) International Union of Pharmacology LVIII: update on the P2Y G protein-coupled nucleotide receptors: from molecular mechanisms and pathophysiology to therapy. Pharmacol Rev 58:281-341

5. Fredholm BB, IJzerman AP, Jacobson KA, Klotz KN, Linden J (2001) International Union of Pharmacology. XXV. Nomenclature and classification of adenosine receptors. Pharmacol Rev 53:527-552

6. Zimmermann H (2000) Extracellular metabolism of ATP and other nucleotides. Naunyn Schmiedebergs Arch Pharmacol 362:299-309

7. Yegutkin GG (2008) Nucleotide- and nucleoside-converting ectoenzymes: important modulators of purinergic signalling cascade. Biochim Biophys Acta 1783:673-694

8. Zimmermann H (2006) Nucleotide signaling in nervous system development. Pflugers Arch 452:573-588

9. Dale N (2008) Dynamic ATP signalling and neural development. J Physiol 586:2429-2436

10. Burnstock G, Ulrich H (2011) Purinergic signaling in embryonic and stem cell development. Cell Mol Life Sci 68:1369-1394

11. Hellsten U, Harland RM, Gilchrist MJ, Hendrix D, Jurka J, Kapitonov V, Ovcharenko I, Putnam NH, Shu S, Taher L, Blitz IL, Blumberg B, Dichmann DS, Dubchak I, Amaya E, Detter JC, Fletcher R, Gerhard DS, Goodstein D, Graves T, Grigoriev IV, Grimwood J, Kawashima T, Lindquist E, Lucas SM, Mead PE, Mitros T, Ogino H, Ohta Y, Poliakov AV, Pollet N, Robert J, Salamov A, Sater AK, Schmutz J, Terry A, Vize PD, Warren WC, Wells D, Wills A, Wilson RK, Zimmerman LB, Zorn AM, Grainger R, Grammer T, Khokha MK, Richardson PM, Rokhsar 
DS (2010) The genome of the Western clawed frog Xenopus tropicalis. Science 328:633-636

12. Solnica-Krezel L (2005) Conserved patterns of cell movements during vertebrate gastrulation. Curr Biol 15:R213-228

13. Theiler K (1989) The house mouse: atlas of embryonic development. Springer, New York

14. Downs KM, Davies T (1993) Staging of gastrulating mouse embryos by morphological landmarks in the dissecting microscope. Development 118:1255-1266

15. Nieuwkoop PD, Faber J (1994) Normal table of Xenopus laevis (Daudin). Garland, New York

16. Hamburger V, Hamilton HL (1992) A series of normal stages in the development of the chick embryo. 1951. Dev Dyn 195:231-272

17. Kimmel CB, Ballard WW, Kimmel SR, Ullmann B, Schilling TF (1995) Stages of embryonic development of the zebrafish. Dev Dyn 203:253-310

18. Souslova V, Cesare P, Ding Y, Akopian AN, Stanfa L, Suzuki R, Carpenter K, Dickenson A, Boyce S, Hill R, Nebenuis-Oosthuizen D, Smith AJ, Kidd EJ, Wood JN (2000) Warm-coding deficits and aberrant inflammatory pain in mice lacking P2X3 receptors. Nature 407:1015-1017

19. Mulryan K, Gitterman DP, Lewis CJ, Vial C, Leckie BJ, Cobb AL, Brown JE, Conley EC, Buell G, Pritchard CA, Evans RJ (2000) Reduced vas deferens contraction and male infertility in mice lacking P2X1 receptors. Nature 403:86-89

20. Sun D, Samuelson LC, Yang T, Huang Y, Paliege A, Saunders T, Briggs J, Schnermann J (2001) Mediation of tubuloglomerular feedback by adenosine: evidence from mice lacking adenosine 1 receptors. Proc Natl Acad Sci USA 98:9983-9988

21. Brone B, Moechars D, Marrannes R, Mercken M, Meert T (2007) $\mathrm{P} 2 \mathrm{X}$ currents in peritoneal macrophages of wild type and $\mathrm{P} 2 \mathrm{X} 4^{-/}$ mice. Immunol Lett 113:83-89

22. Sim JA, Chaumont S, Jo J, Ulmann L, Young MT, Cho K, Buell G, North RA, Rassendren F (2006) Altered hippocampal synaptic potentiation in P2X4 knock-out mice. J Neurosci 26:9006-9009

23. Yang D, Zhang Y, Nguyen HG, Koupenova M, Chauhan AK, Makitalo M, Jones MR, St Hilaire C, Seldin DC, Toselli P, Lamperti E, Schreiber BM, Gavras H, Wagner DD, Ravid K (2006) The A2B adenosine receptor protects against inflammation and excessive vascular adhesion. J Clin Invest 116:1913-1923

24. Bassil AK, Bourdu S, Townson KA, Wheeldon A, Jarvie EM, Zebda N, Abuin A, Grau E, Livi GP, Punter L, Latcham J, Grimes AM, Hurp DP, Downham KM, Sanger GJ, Winchester WJ, Morrison AD, Moore GB (2009) UDP-glucose modulates gastric function through $\mathrm{P} 2 \mathrm{Y} 14$ receptor-dependent and independent mechanisms. Am J Physiol Gastrointest Liver Physiol 296:G923-930

25. Magdaleno S, Jensen P, Brumwell CL, Seal A, Lehman K, Asbury A, Cheung T, Cornelius T, Batten DM, Eden C, Norland SM, Rice DS, Dosooye N, Shakya S, Mehta P, Curran T (2006) BGEM: an in situ hybridization database of gene expression in the embryonic and adult mouse nervous system. PLoS Biol 4:e86

26. Diez-Roux G, Banfi S, Sultan M, Geffers L, Anand S, Rozado D, Magen A, Canidio E, Pagani M, Peluso I, Lin-Marq N, Koch M, Bilio M, Cantiello I, Verde R, De Masi C, Bianchi SA, Cicchini J, Perroud E, Mehmeti S, Dagand E, Schrinner S, Nurnberger A, Schmidt K, Metz K, Zwingmann C, Brieske N, Springer C, Hernandez AM, Herzog S, Grabbe F, Sieverding C, Fischer B, Schrader K, Brockmeyer M, Dettmer S, Helbig C, Alunni V, Battaini MA, Mura C, Henrichsen CN, Garcia-Lopez R, Echevarria D, Puelles E, Garcia-Calero E, Kruse S, Uhr M, Kauck C, Feng G, Milyaev N, Ong CK, Kumar L, Lam M, Semple CA, Gyenesei A, Mundlos S, Radelof U, Lehrach H, Sarmientos P, Reymond A, Davidson DR, Dolle P, Antonarakis SE, Yaspo ML, Martinez S, Baldock RA, Eichele G, Ballabio A (2011) A high-resolution anatomical atlas of the transcriptome in the mouse embryo. PLoS Biol 9:e1000582

27. Cui XS, Li XY, Shen XH, Bae YJ, Kang JJ, Kim NH (2007) Transcription profile in mouse four-cell, morula, and blastocyst: genes implicated in compaction and blastocoel formation. Mol Reprod Dev 74:133-143

28. Kucenas S, Li Z, Cox JA, Egan TM, Voigt MM (2003) Molecular characterization of the zebrafish $\mathrm{P} 2 \mathrm{X}$ receptor subunit gene family. Neuroscience 121:935-945

29. Boehmler W, Petko J, Woll M, Frey C, Thisse B, Thisse C, Canfield VA, Levenson R (2009) Identification of zebrafish A2 adenosine receptors and expression in developing embryos. Gene Expr Patterns 9:144-151

30. Ryten M, Hoebertz A, Burnstock G (2001) Sequential expression of three receptor subtypes for extracellular ATP in developing rat skeletal muscle. Dev Dyn 221:331-341

31. Masse K, Bhamra S, Allsop G, Dale N, Jones EA (2010) Ectophosphodiesterase/nucleotide phosphohydrolase (Enpp) nucleotidases: cloning, conservation and developmental restriction. Int $\mathrm{J}$ Dev Biol 54:181-193

32. Masse K, Eason R, Bhamra S, Dale N, Jones EA (2006) Comparative genomic and expression analysis of the conserved NTPDase gene family in Xenopus. Genomics 87:366-381

33. Bachner D, Ahrens M, Betat N, Schroder D, Gross G (1999) Developmental expression analysis of murine autotaxin (ATX). Mech Dev 84:121-125

34. Ohuchi H, Hayashibara Y, Matsuda H, Onoi M, Mitsumori M, Tanaka M, Aoki J, Arai H, Noji S (2007) Diversified expression patterns of autotaxin, a gene for phospholipid-generating enzyme during mouse and chicken development. Dev Dyn 236:1134 1143

35. Nakanaga K, Hama K, Aoki J (2010) Autotaxin - an LPA producing enzyme with diverse functions. J Biochem 148:13-24

36. Nureddin A, Epsaro E, Kiessling AA (1990) Purines inhibit the development of mouse embryos in vitro. J Reprod Fertil 90:455-464

37. Zylka MJ, Sowa NA, Taylor-Blake B, Twomey MA, Herrala A, Voikar V, Vihko P (2008) Prostatic acid phosphatase is an ectonucleotidase and suppresses pain by generating adenosine. Neuron 60:111-122

38. Zimmermann H (2009) Prostatic acid phosphatase, a neglected ectonucleotidase. Purinergic Signal 5:273-275

39. Quintero IB, Araujo CL, Pulkka AE, Wirkkala RS, Herrala AM, Eskelinen EL, Jokitalo E, Hellstrom PA, Tuominen HJ, Hirvikoski PP, Vihko PT (2007) Prostatic acid phosphatase is not a prostate specific target. Cancer Res 67:6549-6554

40. Taylor-Blake B, Zylka MJ (2010) Prostatic acid phosphatase is expressed in peptidergic and nonpeptidergic nociceptive neurons of mice and rats. PLoS One 5:e8674

41. Boldogkoi Z, Schutz B, Sallach J, Zimmer A (2002) P2X(3) receptor expression at early stage of mouse embryogenesis. Mech Dev 118:255-260

42. Norton WH, Rohr KB, Burnstock G (2000) Embryonic expression of a P2X(3) receptor encoding gene in zebrafish. Mech Dev 99:149-152

43. Kucenas S, Soto F, Cox JA, Voigt MM (2006) Selective labeling of central and peripheral sensory neurons in the developing zebrafish using $\mathrm{P} 2 \mathrm{X}(3)$ receptor subunit transgenes. Neuroscience 138:641-652

44. Appelbaum L, Skariah G, Mourrain P, Mignot E (2007) Comparative expression of $\mathrm{p} 2 \mathrm{x}$ receptors and ecto-nucleoside triphosphate diphosphohydrolase 3 in hypocretin and sensory neurons in zebrafish. Brain Res 1174:66-75

45. Robaye B, Ghanem E, Wilkin F, Fokan D, Van Driessche W, Schurmans S, Boeynaems JM, Beauwens R (2003) Loss of nucleotide regulation of epithelial chloride transport in the jejunum of P2Y4-null mice. Mol Pharmacol 63:777-783 
46. Cockayne DA, Dunn PM, Zhong Y, Rong W, Hamilton SG, Knight GE, Ruan HZ, Ma B, Yip P, Nunn P, McMahon SB, Burnstock G, Ford AP (2005) P2X2 knockout mice and P2X2/ $\mathrm{P} 2 \mathrm{X} 3$ double knockout mice reveal a role for the $\mathrm{P} 2 \mathrm{X} 2$ receptor subunit in mediating multiple sensory effects of ATP. J Physiol 567:621-639

47. Cockayne DA, Hamilton SG, Zhu QM, Dunn PM, Zhong Y, Novakovic S, Malmberg AB, Cain G, Berson A, Kassotakis L, Hedley L, Lachnit WG, Burnstock G, McMahon SB, Ford AP (2000) Urinary bladder hyporeflexia and reduced pain-related behaviour in P2X3-deficient mice. Nature 407:1011-1015

48. Lewis C, Neidhart S, Holy C, North RA, Buell G, Surprenant A (1995) Coexpression of P2X2 and P2X3 receptor subunits can account for ATP-gated currents in sensory neurons. Nature 377:432-435

49. Salvatore CA, Tilley SL, Latour AM, Fletcher DS, Koller BH, Jacobson MA (2000) Disruption of the A(3) adenosine receptor gene in mice and its effect on stimulated inflammatory cells. $\mathrm{J}$ Biol Chem 275:4429-4434

50. Eckle T, Fullbier L, Wehrmann M, Khoury J, Mittelbronn M, Ibla J, Rosenberger P, Eltzschig HK (2007) Identification of ectonucleotidases CD39 and CD73 in innate protection during acute lung injury. J Immunol 178:8127-8137

51. Masse K, Bhamra S, Eason R, Dale N, Jones EA (2007) Purinemediated signalling triggers eye development. Nature 449:10581062

52. Fabre JE, Nguyen M, Latour A, Keifer JA, Audoly LP, Coffman TM, Koller BH (1999) Decreased platelet aggregation, increased bleeding time and resistance to thromboembolism in P2Y1deficient mice. Nat Med 5:1199-1202

53. Leon C, Hechler B, Freund M, Eckly A, Vial C, Ohlmann P, Dierich A, LeMeur M, Cazenave JP, Gachet C (1999) Defective platelet aggregation and increased resistance to thrombosis in purinergic P2Y(1) receptor-null mice. J Clin Invest 104:17311737

54. Grindley JC, Davidson DR, Hill RE (1995) The role of Pax-6 in eye and nasal development. Development 121:1433-1442

55. Kucenas S, Cox JA, Soto F, Lamora A, Voigt MM (2009) Ectodermal P2X receptor function plays a pivotal role in craniofacial development of the zebrafish. Purinergic Signal 5:395-407

56. Funakoshi H, Chan TO, Good JC, Libonati JR, Piuhola J, Chen X, MacDonnell SM, Lee LL, Herrmann DE, Zhang J, Martini J, Palmer TM, Sanbe A, Robbins J, Houser SR, Koch WJ, Feldman AM (2006) Regulated overexpression of the A1-adenosine receptor in mice results in adverse but reversible changes in cardiac morphology and function. Circulation 114:2240-2250

57. Zhao Z, Yaar R, Ladd D, Cataldo LM, Ravid K (2002) Overexpression of A3 adenosine receptors in smooth, cardiac, and skeletal muscle is lethal to embryos. Microvasc Res 63:61-69

58. Tsuchimori N, Miyashiro S, Shibai H, Ikegami S (1988) Adenosine induces dormancy in starfish blastulas. Development 103:345-351

59. Adair TH, Montani JP, Strick DM, Guyton AC (1989) Vascular development in chick embryos: a possible role for adenosine. Am J Physiol 256:H240-246

60. Ghatpande SK, Billington CJ Jr, Rivkees SA, Wendler CC (2008) Hypoxia induces cardiac malformations via A1 adenosine receptor activation in chicken embryos. Birth Defects Res A Clin Mol Teratol 82:121-130

61. Iijima R, Kunieda T, Yamaguchi S, Kamigaki H, Fujii-Taira I, Sekimizu K, Kubo T, Natori S, Homma KJ (2008) The extracellular adenosine deaminase growth factor, ADGF/CECR1, plays a role in Xenopus embryogenesis via the adenosine/P1 receptor. J Biol Chem 283:2255-2264

62. Knudsen TB, Blackburn MR, Chinsky JM, Airhart MJ, Kellems RE (1991) Ontogeny of adenosine deaminase in the mouse decidua and placenta: immunolocalization and embryo transfer studies. Biol Reprod 44:171-184

63. Chechik BE, Sengupta S, Hibi T, Fernandes B (1985) Immunomorphological localization of adenosine deaminase in rat tissues during ontogeny. Histochem J 17:153-170

64. Wakamiya M, Blackburn MR, Jurecic R, McArthur MJ, Geske RS, Cartwright J Jr, Mitani K, Vaishnav S, Belmont JW, Kellems $\mathrm{RE}$ et al (1995) Disruption of the adenosine deaminase gene causes hepatocellular impairment and perinatal lethality in mice. Proc Natl Acad Sci USA 92:3673-3677

65. Migchielsen AA, Breuer ML, van Roon MA, te Riele H, Zurcher C, Ossendorp F, Toutain S, Hershfield MS, Berns A, Valerio D (1995) Adenosine-deaminase-deficient mice die perinatally and exhibit liver-cell degeneration, atelectasis and small intestinal cell death. Nat Genet 10:279-287

66. Nofech-Mozes Y, Blaser SI, Kobayashi J, Grunebaum E, Roifman CM (2007) Neurologic abnormalities in patients with adenosine deaminase deficiency. Pediatr Neurol 37:218-221

67. Franco R, Casado V, Ciruela F, Saura C, Mallol J, Canela EI, Lluis C (1997) Cell surface adenosine deaminase: much more than an ectoenzyme. Prog Neurobiol 52:283-294

68. Wolpert L (1969) Positional information and the spatial pattern of cellular differentiation. J Theor Biol 25:1-47

69. Bray SJ (2006) Notch signalling: a simple pathway becomes complex. Nat Rev Mol Cell Biol 7:678-689

70. Ingham PW, McMahon AP (2001) Hedgehog signaling in animal development: paradigms and principles. Genes Dev 15:30593087

71. van Amerongen R, Nusse R (2009) Towards an integrated view of Wnt signaling in development. Development 136:3205-3214

72. Moustakas A, Heldin CH (2009) The regulation of TGFbeta signal transduction. Development 136:3699-3714

73. Dorey K, Amaya E (2010) FGF signalling: diverse roles during early vertebrate embryogenesis. Development 137:3731-3742

74. Campo-Paysaa F, Marletaz F, Laudet V, Schubert M (2008) Retinoic acid signaling in development: tissue-specific functions and evolutionary origins. Genesis 46:640-656

75. Mic FA, Molotkov A, Benbrook DM, Duester G (2003) Retinoid activation of retinoic acid receptor but not retinoid $\mathrm{X}$ receptor is sufficient to rescue lethal defect in retinoic acid synthesis. Proc Natl Acad Sci USA 100:7135-7140

76. Benazet JD, Zeller R (2009) Vertebrate limb development: moving from classical morphogen gradients to an integrated 4dimensional patterning system. Cold Spring Harb Perspect Biol 1:a001339

77. von Albertini M, Palmetshofer A, Kaczmarek E, Koziak K, Stroka D, Grey ST, Stuhlmeier KM, Robson SC (1998) Extracellular ATP and ADP activate transcription factor NF-kappa B and induce endothelial cell apoptosis. Biochem Biophys Res Commun 248:822-829

78. Basheer R, Rainnie DG, Porkka-Heiskanen T, Ramesh V, McCarley RW (2001) Adenosine, prolonged wakefulness, and A1-activated NF-kappaB DNA binding in the basal forebrain of the rat. Neuroscience 104:731-739

79. Korcok J, Raimundo LN, Ke HZ, Sims SM, Dixon SJ (2004) Extracellular nucleotides act through $\mathrm{P} 2 \mathrm{X} 7$ receptors to activate NF-kappaB in osteoclasts. J Bone Miner Res 19:642-651

80. Fishman P, Bar-Yehuda S, Ohana G, Barer F, Ochaion A, Erlanger A, Madi L (2004) An agonist to the A3 adenosine receptor inhibits colon carcinoma growth in mice via modulation of GSK-3 beta and NF-kappa B. Oncogene 23:2465-2471

81. Schafer R, Hartig R, Sedehizade F, Welte T, Reiser G (2006) Adenine nucleotides inhibit proliferation of the human lung adenocarcinoma cell line LXF-289 by activation of nuclear factor kappaB1 and mitogen-activated protein kinase pathways. FEBS J 273:3756-3767 
82. Liu Q, Li J, Khoury J, Colgan SP, Ibla JC (2009) Adenosine signaling mediates SUMO-1 modification of IkappaBalpha during hypoxia and reoxygenation. J Biol Chem 284:13686-13695

83. Molliver DC, Cook SP, Carlsten JA, Wright DE, McCleskey EW (2002) ATP and UTP excite sensory neurons and induce CREB phosphorylation through the metabotropic receptor, P2Y2. Eur J Neurosci 16:1850-1860

84. Lynge J, Schulte G, Nordsborg N, Fredholm BB, Hellsten Y (2003) Adenosine A 2B receptors modulate cAMP levels and induce CREB but not ERK1/2 and p38 phosphorylation in rat skeletal muscle cells. Biochem Biophys Res Commun 307:180-187

85. Gavala ML, Pfeiffer ZA, Bertics PJ (2008) The nucleotide receptor P2RX7 mediates ATP-induced CREB activation in human and murine monocytic cells. J Leukoc Biol 84:1159-1171

86. Dooley R, Mashukova A, Toetter B, Hatt H, Neuhaus EM (2011) Purinergic receptor antagonists inhibit odorant-mediated CREB phosphorylation in sustentacular cells of mouse olfactory epithelium. BMC Neurosci 12:86

87. Sandell LL, Sanderson BW, Moiseyev G, Johnson T, Mushegian A, Young K, Rey JP, Ma JX, Staehling-Hampton K, Trainor PA (2007) RDH10 is essential for synthesis of embryonic retinoic acid and is required for limb, craniofacial, and organ development. Genes Dev 21:1113-1124

88. Niederreither K, Subbarayan V, Dolle P, Chambon P (1999) Embryonic retinoic acid synthesis is essential for early mouse post-implantation development. Nat Genet 21:444-448

89. Pennimpede T, Cameron DA, MacLean GA, Li H, Abu-Abed S, Petkovich M (2010) The role of CYP26 enzymes in defining appropriate retinoic acid exposure during embryogenesis. Birth Defects Res A Clin Mol Teratol 88:883-894

90. Sirbu IO, Gresh L, Barra J, Duester G (2005) Shifting boundaries of retinoic acid activity control hindbrain segmental gene expression. Development 132:2611-2622

91. Abu-Abed S, Dolle P, Metzger D, Beckett B, Chambon P, Petkovich M (2001) The retinoic acid-metabolizing enzyme, CYP26A1, is essential for normal hindbrain patterning, vertebral identity, and development of posterior structures. Genes Dev 15:226-240

92. Mark M, Ghyselinck NB, Chambon P (2009) Function of retinoic acid receptors during embryonic development. Nucl Recept Signal 7:e002

93. Slakey LL, Cosimini K, Earls JP, ThomasC GEL (1986) Simulation of extracellular nucleotide hydrolysis and determination of kinetic constants for the ectonucleotidases. J Biol Chem 261:15505-15507

94. James S, Richardson PJ (1993) Production of adenosine from extracellular ATP at the striatal cholinergic synapse. J Neurochem 60:219-227

95. Dale N (1998) Delayed production of adenosine underlies temporal modulation of swimming in frog embryo. J Physiol (Lond) 511:265-272

96. Dale N, Frenguelli BG (2011) Measurement of purine release with microelectrode biosensors. Purinergic Signal. doi:10.1007/ s11302-011-9273-4

97. Hoffmann C, Gaietta G, Bunemann M, Adams SR, OberdorffMaass S, Behr B, Vilardaga JP, Tsien RY, Ellisman MH, Lohse MJ (2005) A FlAsH-based FRET approach to determine G protein-coupled receptor activation in living cells. Nat Methods 2:171-176

98. Rivkees SA (1995) The ontogeny of cardiac and neural A1 adenosine receptor expression in rats. Brain Res Dev Brain Res $89: 202-213$

99. Weaver DR (1996) A1-adenosine receptor gene expression in fetal rat brain. Brain Res Dev Brain Res 94:205-223

100. Cheung KK, Chan WY, Burnstock G (2005) Expression of P2X purinoceptors during rat brain development and their inhibitory role on motor axon outgrowth in neural tube explant cultures. Neuroscience 133:937-945

101. Brandle U, Zenner HP, Ruppersberg JP (1999) Gene expression of P2X-receptors in the developing inner ear of the rat. Neurosci Lett 273:105-108

102. Liang SX, Motin L, Moussa CE, Lavidis NA, Phillips WD (2001) Spatial distribution and developmental appearance of postjunctional P2X1 receptors on smooth muscle cells of the mouse vas deferens. Synapse 42:1-11

103. Hoffman BG, Zavaglia B, Witzsche J, Ruiz de Algara T, Beach M, Hoodless PA, Jones SJ, Marra MA, Helgason CD (2008) Identification of transcripts with enriched expression in the developing and adult pancreas. Genome Biol 9:R99

104. Ruan HZ, Moules E, Burnstock G (2004) Changes in P2X3 purinoceptors in sensory ganglia of the mouse during embryonic and postnatal development. Histochem Cell Biol 122:539-551

105. Kidd EJ, Miller KJ, Sansum AJ, Humphrey PP (1998) Evidence for P2X3 receptors in the developing rat brain. Neuroscience $87: 533-539$

106. Cheung KK, Burnstock G (2002) Localization of P2X3 receptors and coexpression with $\mathrm{P} 2 \mathrm{X} 2$ receptors during rat embryonic neurogenesis. J Comp Neurol 443:368-382

107. Cheung KK, Coutinho-Silva R, Chan WY, Burnstock G (2007) Early expression of adenosine 5'-triphosphate-gated P2X7 receptors in the developing rat pancreas. Pancreas 35:164-168

108. Freeman TC, Dixon AK, Campbell EA, Tait TM, Richardson PJ, Rice KM, Maslen GL, Metcalfe AD, Streuli CH, Bentley DR (1998) Expression mapping of mouse genes. MGI Direct Data Submission J:46439.

109. Hahnel AC, Rappolee DA, Millan JL, Manes T, Ziomek CA, Theodosiou NG, Werb Z, Pedersen RA, Schultz GA (1990) Two alkaline phosphatase genes are expressed during early development in the mouse embryo. Development 110:555-564

110. Langer D, Ikehara Y, Takebayashi H, Hawkes R, Zimmermann H (2007) The ectonucleotidases alkaline phosphatase and nucleoside triphosphate diphosphohydrolase 2 are associated with subsets of progenitor cell populations in the mouse embryonic, postnatal and adult neurogenic zones. Neuroscience 150:863-879

111. Brun-Heath I, Ermonval M, Chabrol E, Xiao J, Palkovits M, Lyck R, Miller F, Couraud PO, Mornet E, Fonta C (2011) Differential expression of the bone and the liver tissue non-specific alkaline phosphatase isoforms in brain tissues. Cell Tissue Res 343:521-536

112. Sharov AA, Piao Y, Matoba R, Dudekula DB, Qian Y, VanBuren V, Falco G, Martin PR, Stagg CA, Bassey UC, Wang Y, Carter MG, Hamatani T, Aiba K, Akutsu H, Sharova L, Tanaka TS, Kimber WL, Yoshikawa T, Jaradat SA, Pantano S, Nagaraja R, Boheler KR, Taub D, Hodes RJ, Longo DL, Schlessinger D, Keller J, Klotz E, Kelsoe G, Umezawa A, Vescovi AL, Rossant J, Kunath T, Hogan BL, Curci A, D’Urso M, Kelso J, Hide W, Ko MS (2003) Transcriptome analysis of mouse stem cells and early embryos. PLoS Biol 1:E74

113. Brown P, Dale N (2000) Adenosine A1 receptors modulate high voltage-activated $\mathrm{Ca} 2+$ currents and motor pattern generation in the xenopus embryo. J Physiol 525(Pt 3):655-667

114. Cheng AW, Kong LW, Tung EK, Siow NL, Choi RC, Zhu SQ, Peng BH, Tsim KW (2003) cDNA encodes Xenopus P2Y(1) nucleotide receptor: expression at the neuromuscular junctions. Neuroreport 14:351-357

115. Bogdanov YD, Dale L, King BF, Whittock N, Burnstock G (1997) Early expression of a novel nucleotide receptor in the neural plate of Xenopus embryos. J Biol Chem 272:12583-12590

116. Devader C, Drew CM, Geach TJ, Tabler J, Townsend-Nicholson A, Dale L (2007) A novel nucleotide receptor in Xenopus activates the cAMP second messenger pathway. FEBS Lett 581:5332-5336 
117. Durand IH, Green RD (2001) Cloning of a chick A3 adenosine receptor: characterization of ligand binding and receptor-effector coupling of chick A1 and A3 adenosine receptors. Naunyn Schmiedebergs Arch Pharmacol 363:81-86

118. Soto F, Krause U, Borchardt K, Ruppelt A (2003) Cloning, tissue distribution and functional characterization of the chicken P2X1 receptor. FEBS Lett 533:54-58

119. Ruppelt A, Liang BT, Soto F (1999) Cloning, functional characterization and developmental expression of a P2X receptor from chick embryo. Prog Brain Res 120:81-90

120. Ruppelt A, Ma W, Borchardt K, Silberberg SD, Soto F (2001) Genomic structure, developmental distribution and functional properties of the chicken P2X(5) receptor. J Neurochem 77:1256-1265

121. Meyer MP, Groschel-Stewart U, Robson T, Burnstock G (1999) Expression of two ATP-gated ion channels, P2X5 and P2X6, in developing chick skeletal muscle. Dev Dyn 216:442-449

122. Bo X, Schoepfer R, Burnstock G (2000) Molecular cloning and characterization of a novel ATP P2X receptor subtype from embryonic chick skeletal muscle. J Biol Chem 275:14401-14407

123. Choi RC, Man ML, Ling KK, Ip NY, Simon J, Barnard EA, Tsim KW (2001) Expression of the P2Y1 nucleotide receptor in chick muscle: its functional role in the regulation of acetylcholinesterase and acetylcholine receptor. J Neurosci 21:9224-9234

124. Meyer MP, Clarke JD, Patel K, Townsend-Nicholson A, Burnstock G (1999) Selective expression of purinoceptor cP2Y1 suggests a role for nucleotide signalling in development of the chick embryo. Dev Dyn 214:152-158

125. Johansson B, Halldner L, Dunwiddie TV, Masino SA, Poelchen W, Gimenez-Llort L, Escorihuela RM, Fernandez-Teruel A, Wiesenfeld-Hallin Z, Xu XJ, Hardemark A, Betsholtz C, Herlenius E, Fredholm BB (2001) Hyperalgesia, anxiety, and decreased hypoxic neuroprotection in mice lacking the adenosine A1 receptor. Proc Natl Acad Sci USA 98:9407-9412

126. Ledent C, Vaugeois JM, Schiffmann SN, Pedrazzini T, El Yacoubi M, Vanderhaeghen JJ, Costentin J, Heath JK, Vassart G, Parmentier M (1997) Aggressiveness, hypoalgesia and high blood pressure in mice lacking the adenosine A2a receptor. Nature 388:674-678

127. Chen JF, Huang Z, Ma J, Zhu J, Moratalla R, Standaert D, Moskowitz MA, Fink JS, Schwarzschild MA (1999) A(2A) adenosine receptor deficiency attenuates brain injury induced by transient focal ischemia in mice. J Neurosci 19:9192-9200

128. Hua X, Kovarova M, Chason KD, Nguyen M, Koller BH, Tilley SL (2007) Enhanced mast cell activation in mice deficient in the A2b adenosine receptor. J Exp Med 204:117-128

129. Yamamoto K, Sokabe T, Matsumoto T, Yoshimura K, Shibata M, Ohura N, Fukuda T, Sato T, Sekine K, Kato S, Isshiki M, Fujita T, Kobayashi M, Kawamura K, Masuda H, Kamiya A, Ando J (2006) Impaired flow-dependent control of vascular tone and remodeling in P2X4-deficient mice. Nat Med 12:133-137

130. Solle M, Labasi J, Perregaux DG, Stam E, Petrushova N, Koller BH, Griffiths RJ, Gabel CA (2001) Altered cytokine production in mice lacking $\mathrm{P} 2 \mathrm{X}(7)$ receptors. J Biol Chem 276:125-132

131. Chessell IP, Hatcher JP, Bountra C, Michel AD, Hughes JP, Green P, Egerton J, Murfin M, Richardson J, Peck WL, Grahames CB, Casula MA, Yiangou Y, Birch R, Anand P, Buell GN (2005) Disruption of the P2X7 purinoceptor gene abolishes chronic inflammatory and neuropathic pain. Pain 114:386-396

132. Homolya L, Watt WC, Lazarowski ER, Koller BH, Boucher RC (1999) Nucleotide-regulated calcium signaling in lung fibroblasts and epithelial cells from normal and P2Y(2) receptor $(-/-)$ mice. J Biol Chem 274:26454-26460

133. Cressman VL, Lazarowski E, Homolya L, Boucher RC, Koller BH, Grubb BR (1999) Effect of loss of P2Y(2) receptor gene expression on nucleotide regulation of murine epithelial $\mathrm{Cl}(-)$ transport. J Biol Chem 274:26461-26468

134. Bar I, Guns PJ, Metallo J, Cammarata D, Wilkin F, Boeynams JM, Bult H, Robaye B (2008) Knockout mice reveal a role for P2Y6 receptor in macrophages, endothelial cells, and vascular smooth muscle cells. Mol Pharmacol 74:777-784

135. Foster CJ, Prosser DM, Agans JM, Zhai Y, Smith MD, Lachowicz JE, Zhang FL, Gustafson E, Monsma FJ Jr, Wiekowski MT, Abbondanzo SJ, Cook DN, Bayne ML, Lira SA, Chintala MS (2001) Molecular identification and characterization of the platelet ADP receptor targeted by thienopyridine antithrombotic drugs. J Clin Invest 107:1591-1598

136. Andre P, Delaney SM, LaRocca T, Vincent D, DeGuzman F, Jurek M, Koller B, Phillips DR, Conley PB (2003) P2Y12 regulates platelet adhesion/activation, thrombus growth, and thrombus stability in injured arteries. J Clin Invest 112:398-406

137. Fabre AC, Malaval C, Ben Addi A, Verdier C, Pons V, Serhan N, Lichtenstein L, Combes G, Huby T, Briand F, Collet X, Nijstad N, Tietge UJ, Robaye B, Perret B, Boeynaems JM, Martinez LO (2010) P2Y13 receptor is critical for reverse cholesterol transport. Hepatology 52:1477-1483

138. Enjyoji K, Sevigny J, Lin Y, Frenette PS, Christie PD, Esch JS 2nd, Imai M, Edelberg JM, Rayburn H, Lech M, Beeler DL, Csizmadia E, Wagner DD, Robson SC, Rosenberg RD (1999) Targeted disruption of cd39/ATP diphosphohydrolase results in disordered hemostasis and thromboregulation. Nat Med 5:1010 1017

139. Castrop H, Huang Y, Hashimoto S, Mizel D, Hansen P, Theilig F, Bachmann S, Deng C, Briggs J, Schnermann J (2004) Impairment of tubuloglomerular feedback regulation of GFR in ecto-5'nucleotidase/CD73-deficient mice. J Clin Invest 114:634-642

140. Koszalka P, Ozuyaman B, Huo Y, Zernecke A, Flogel U, Braun N, Buchheiser A, Decking UK, Smith ML, Sevigny J, Gear A, Weber AA, Molojavyi A, Ding Z, Weber C, Ley K, Zimmermann H, Godecke A, Schrader J (2004) Targeted disruption of cd73/ ecto-5'-nucleotidase alters thromboregulation and augments vascular inflammatory response. Circ Res 95:814-821

141. Babij P, Roudier M, Graves T, Han CY, Chhoa M, Li CM, Juan T, Morony S, Grisanti M, Li X, Yu L, Dwyer D, Lloyd DJ, Bass MB, Richards WG, Ebeling C, Amato J, Carlson G (2009) New variants in the Enpp 1 and Ptpn6 genes cause low BMD, crystal-related arthropathy, and vascular calcification. J Bone Miner Res 24:1552-1564

142. Okawa A, Nakamura I, Goto S, Moriya H, Nakamura Y, Ikegawa S (1998) Mutation in Npps in a mouse model of ossification of the posterior longitudinal ligament of the spine. Nat Genet 19:271-273

143. van Meeteren LA, Ruurs P, Stortelers C, Bouwman P, van Rooijen MA, Pradere JP, Pettit TR, Wakelam MJ, Saulnier-Blache JS, Mummery CL, Moolenaar WH, Jonkers J (2006) Autotaxin, a secreted lysophospholipase D, is essential for blood vessel formation during development. Mol Cell Biol 26:5015-5022

144. Fotopoulou S, Oikonomou N, Grigorieva E, Nikitopoulou I, Paparountas T, Thanassopoulou A, Zhao Z, Xu Y, Kontoyiannis DL, Remboutsika E, Aidinis V (2010) ATX expression and LPA signalling are vital for the development of the nervous system. Dev Biol 339:451-464

145. Narisawa S, Frohlander N, Millan JL (1997) Inactivation of two mouse alkaline phosphatase genes and establishment of a model of infantile hypophosphatasia. Dev Dyn 208:432-446

146. Dehghani H, Narisawa S, Millan JL, Hahnel AC (2000) Effects of disruption of the embryonic alkaline phosphatase gene on preimplantation development of the mouse. Developmental dynamics: an official publication of the American Association of Anatomists 217:440-448

147. Kalin RE, Banziger-Tobler NE, Detmar M, Brandli AW (2009) An in vivo chemical library screen in Xenopus tadpoles reveals 
novel pathways involved in angiogenesis and lymphangiogenesis. Blood 114:1110-1122

148. Gerhart J, Danilchik M, Doniach T, Roberts S, Rowning B, Stewart R (1989) Cortical rotation of the Xenopus egg: consequences for the anteroposterior pattern of embryonic dorsal development. Development 107(Suppl):37-51
149. Ludlow MJ, Durai L, Ennion SJ (2009) Functional characterization of intracellular Dictyostelium discoideum $\mathrm{P} 2 \mathrm{X}$ receptors. J Biol Chem 284:35227-35239

150. Fountain SJ, Parkinson K, Young MT, Cao L, Thompson CR, North RA (2007) An intracellular P2X receptor required for osmoregulation in Dictyostelium discoideum. Nature 448:200-203 